\title{
Seismic stratigraphic record of the Amundsen Sea Embayment shelf from pre-glacial to recent times: Evidence for a dynamic West Antarctic ice sheet
}

\author{
Karsten Gohl ${ }^{\text {a,* }}$, Gabriele Uenzelmann-Neben ${ }^{\text {a }}$, Robert D. Larter ${ }^{\text {b }}$, Claus-Dieter Hillenbrand ${ }^{\mathrm{b}}$, \\ Katharina Hochmuth ${ }^{\mathrm{a}}$, Thomas Kalberg ${ }^{\mathrm{a}}$, Estella Weigelt ${ }^{\mathrm{a}}$, Bryan Davy ${ }^{\mathrm{c}}$, Gerhard Kuhn ${ }^{\mathrm{a}}$, Frank O. Nitsche ${ }^{\mathrm{d}}$ \\ a Alfred Wegener Institute,Helmholtz-Centre for Polar and Marine Research, Bremerhaven, Germany \\ ${ }^{\mathrm{b}}$ British Antarctic Survey, Cambridge, UK \\ ' GNS Science, Avalon, Lower Hutt, New Zealand \\ d Lamont-Doherty Earth Observatory, Palisades, NY, USA
}

\section{A R T I C L E I N F O}

\section{Article history:}

Received 27 February 2013

Received in revised form 12 June 2013

Accepted 18 June 2013

Available online 26 June 2013

Communicated by J.T. Wells

\section{Keywords:}

West Antarctic margin

seismic stratigraphy

ice sheet dynamics

Pine Island Bay

\begin{abstract}
A B S T R A C T
Studies of the sedimentary architecture and characteristics of the Antarctic continental margin provide clues about past ice sheet advance-retreat cycles and help improve constraints for paleo-ice dynamic models since early glacial periods. A first seismostratigraphic analysis of the Amundsen Sea Embayment shelf and slope of West Antarctica reveals insights into the structural architecture of the continental margin and shows stages of sediment deposition, erosion and transport reflecting the history from pre-glacial times to early glaciation and to the late Pleistocene glacial-interglacial cycles. The shelf geometry consists of a large pre- and syn-rift basin in the middle shelf region between basement cropping out on the inner shelf and buried basement ridge and highs on the outer shelf. A subordinate basin within the large basin on the mid-shelf may be associated with motion along an early West Antarctic Rift System branch. At least $4 \mathrm{~km}$ of pre-glacial strata have been eroded from the present inner shelf and coastal hinterland by glacial processes. Six major sedimentary units (ASS-1 to ASS-6) separated by five major erosional unconformities (ASS-u1 to ASS-u5) are distinguished from bottom to top. Unconformity ASS-u4 results from a major truncational event by glacial advance to the middle and outer shelf, which was followed by several episodes of glacial advance and retreat as observed from smaller-scale truncational unconformities within the units above ASS-u4. Some of the eroded sediments were deposited as a progradional wedge that extends the outer shelf by 25 to $65 \mathrm{~km}$ oceanward of the pre-glacial shelf-break. We compare the observed seismic characteristics with those of other Antarctic shelf sequences and assign an Early Cretaceous age to bottom sedimentary unit ASS-1, a Late Cretaceous to Oligocene age to unit ASS-2, an Early to Mid-Miocene age to unit ASS-3, a Mid-Miocene age to unit ASS-4, a Late Miocene to Early Pliocene age to unit ASS-5, and a Pliocene to Pleistocene age to the top unit ASS-6. Buried grounding zone wedges in the upper part of unit ASS-5 on the outer shelf suggest pronounced warming phases and ice sheet retreats during the early Pliocene as observed for the Ross Sea shelf and predicted by paleo-ice sheet models. Our data also reveal that on the middle and outer shelf the flow-path of the Pine Island-Thwaites paleo-ice stream system has remained stationary in the central Pine Island Trough since the earliest glacial advances, which is different from the Ross Sea shelf where glacial troughs shifted more dynamically. This study and its stratigraphic constraints will serve as a basis for future drilling operations required for an improved understanding of processes and mechanisms leading to change in the West Antarctic Ice Sheet, such as the contemporary thinning and grounding line retreat in the Amundsen Sea drainage sector.
\end{abstract}

(c) 2013 Elsevier B.V. All rights reserved.

\section{Introduction}

The reconstruction of the dynamic history of Antarctic Ice Sheet (inlay map of Fig. 1) expansion and retreat since the onset of Southern

\footnotetext{
* Corresponding author at: Alfred Wegener Institute,Helmholtz-Centre for Polar and Marine Research, Dept. of Geosciences, Section of Geophysics, Am Alten Hafen 26, 27568 Bremerhaven, Germany. Tel.: + 4947148311361.

E-mail address: karsten.gohl@awi.de (K. Gohl).
}

Hemisphere glaciation improves our understanding of ice sheet growth and melting processes and thus predictions of future ice-sheet behavior. Because the West Antarctic Ice Sheet (WAIS) has a lower elevation than the East Antarctic Ice Sheet (EAIS) and most of its base is grounded below sea level, the WAIS is likely to have been more sensitive to changes in atmospheric and oceanographic conditions. Results from deep drilling on the Ross Sea shelf have shown that open-water conditions prevailed in that region for long periods of the Early Pliocene (5-3 m.y. ago) (McKay et al., 2009; Naish et al., 2009), suggesting a 


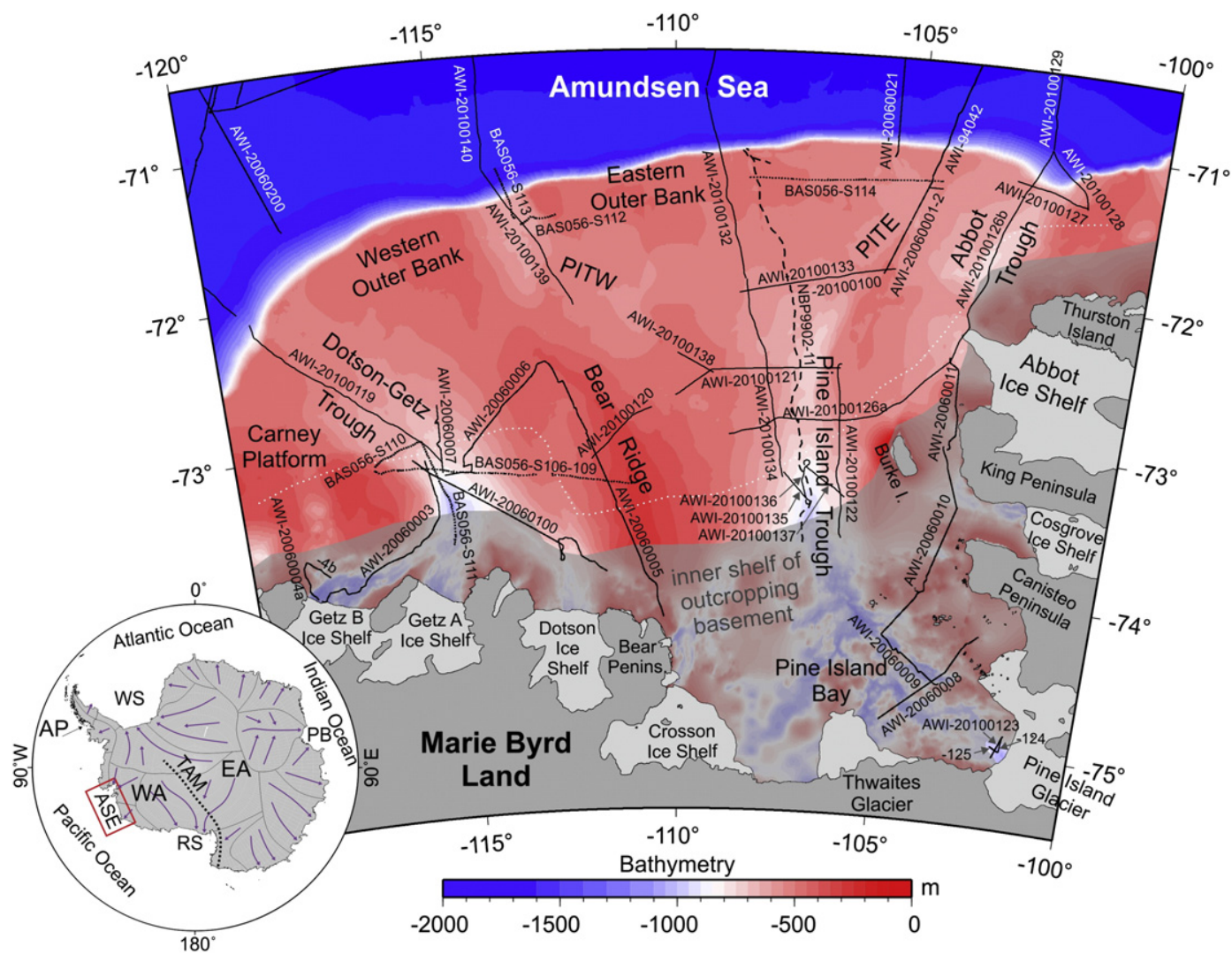

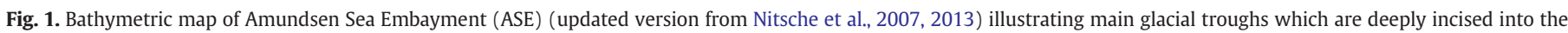

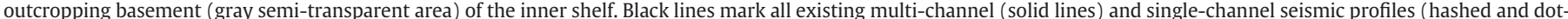

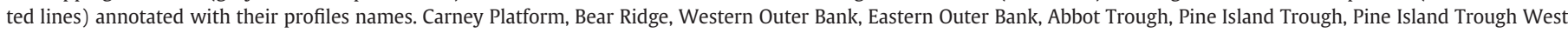

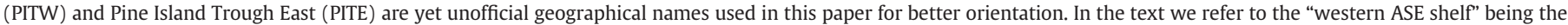

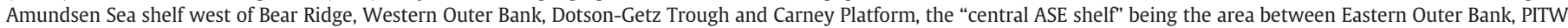

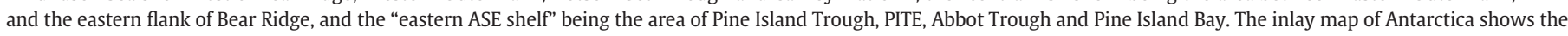

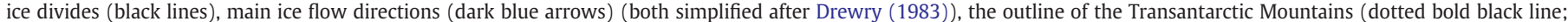

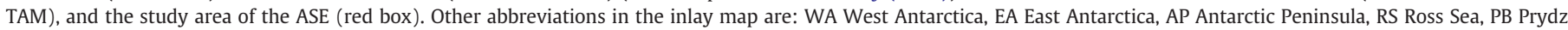
Bay, WS Weddell Sea.

partial or full collapse of the WAIS at times when atmospheric carbon dioxide concentrations were as high as $400 \mathrm{ppm}$ (which will be reached again within the next 5 years on current trends: http://www.esrl.noaa. gov/gmd/ccgg/trends/) and planetary temperatures were up to $3{ }^{\circ} \mathrm{C}$ higher than today. However, the data used for interpreting past WAIS behavior are extremely scarce and may be spatially biased to some degree. The continental shelf and slope drill sites of the Antarctic Drilling Program ANDRILL (Harwood et al., 2009; Levy et al., 2012), the Deep Sea Drilling Project DSDP Leg 28 (Hayes and Frakes, 1975) and the Cape Roberts Project CRP (Cape Roberts Science Team, 1999, 2000) are all located in the western and central regions of the Ross Sea Embayment where the signals interpreted for WAIS dynamics cannot be clearly separated from the influence of ice draining the EAIS through the Transantarctic Mountains (Kerr and Huybrechts, 1999; Bart, 2005).

Ice sheet discharge into the Amundsen Sea Embayment (ASE) (Fig. 1) is entirely sourced from the WAIS (inlay map Fig. 1). The WAIS volume corresponds to an equivalent of 3-5 m eustatic sea level change (Bamber et al., 2009; Fretwell et al., 2013), and about one third of it is stored in drainage basins that discharge through outlet glaciers onto the ASE shelf. The largest drainage systems are those of the Pine Island and Thwaites glaciers, which are known for their current flow acceleration, fast retreat, rapid thinning and high basal melt rates of floating ice at their termini that exceed those of any other Antarctic outlet glacier outside the Antarctic Peninsula (Rignot, 2008; Rignot et al., 2011; Pritchard et al., 2012). Past expansion and retreat of grounded and floating ice across the continental shelf of the ASE must have left signals and traces of glacial sediment accumulation, transport and erosion. Thus, a study of the sedimentary architecture and characteristics of the ASE margin will provide clues of past ice sheet advanceretreat cycles and help improve constraints for paleo-ice dynamic models of the WAIS since early glacial periods.

Seismic profiles acquired over recent years enabled us for the first time to characterize and map seismostratigraphic sequences from a large part of the ASE shelf and slope (Fig. 1). The dataset reveals the architecture of the continental margin, with patterns of sediment deposition, erosion and transport allowing the reconstruction of its history from pre-glacial times to early glaciation and to late Pleistocene glacial-interglacial cycles. We infer ages for the seismostratigraphic units and present a depositional model that serves as a basis for understanding processes of glacial advance and retreat of the WAIS.

\section{Tectonic and depositional setting}

The ASE comprises one of the broadest continental shelves along the Pacific margin of West Antarctica (Fig. 1). Pine Island Bay in the eastern ASE has long been suggested to delineate a Paleozoic/Mesozoic crustal boundary between the Thurston Island block and the Marie Byrd Land block, because its eastern border offsets the coastlines of Marie Byrd Land and the Thurston Island region (Dalziel and Elliot, 1982; Storey, 1991; DiVenere et al., 1994). Plate-tectonic reconstructions infer that this region was a key area for continental rifting and breakup between the Chatham Rise east of New Zealand and Marie Byrd Land starting at $90 \mathrm{Ma}$ (Larter et al., 2002; Eagles et al., 2004; Wobbe et al., 2012), about 10-15 m.y. after the collision of the Hikurangi Plateau with 
Chatham Rise and the cessation of the Gondwana margin subduction (e.g., Davy et al., 2008; Kipf et al., 2012). Airborne magnetic and satellite-derived gravity data grids revealed a series of quasi-linear southwest-northeast directed anomalies on the ASE shelf, interpreted as traces of magmatism along distributed rift axes before breakup (Gohl et al., 2007, 2013). The relatively small crustal thickness of 22-24 km measured on the inner to middle shelf (Gohl et al., 2007) supports the hypothesis of a rifted and thinned continental crust in the ASE. Plate-kinematic reconstructions also suggest that the ASE crust has been subject to deformation along the southern boundary of the Bellingshausen Plate which was active between about 79 and $61 \mathrm{Ma}$ (Eagles et al., 2004; Wobbe et al., 2012). This deformation is supported by observations of northwest-southeast trending lineaments in the potential field grids (Gohl et al., 2007, 2013). A third set of lineaments, striking north-northeast, suggests a third phase of deformation and intrusion, which has been associated with a possible branch of the West Antarctic Rift System (Gohl et al., 2007, 2013). The existence of such a rift branch in the ASE was also postulated by Dalziel (2006) and Jordan et al. (2010). A north-south oriented strike-slip motion with transtensional deformation can be derived for the AmundsenBellingshausen Sea sector of West Antarctica by applying rotation parameters for East-west Antarctic relative motion, as a study by Müller et al. (2007) demonstrated for the Eocene to Miocene. Gohl (2012) and Gohl et al. (2013) suggested that the tectonic-magmatic architecture inherited from the three main crustal deformation phases has placed some degree of control on sedimentation and glacial flow directions at later times as observed by correlation to the directional bathymetric trends of paleo-ice stream troughs (Nitsche et al., 2007).

The earliest recorded multi-channel seismic (MCS) reflection data from the ASE show that at $104^{\circ} \mathrm{W}$ (Fig. 1) the outer shelf and slope sediments have undergone both progradational and aggradational deposition probably since the Middle Miocene (Nitsche et al., 1997, 2000). Aggradation dominated the strata geometry in younger stages. A long single-channel seismic (SCS) profile (Lowe and Anderson, 2002, 2003) follows the main glacial Pine Island Trough and reveals oceanward inclined sediment sequences on the middle shelf north of bedrock cropping out on the inner shelf. The dipping strata typical for Antarctic shelves (e.g., Cooper et al., 1991, 2008; Anderson, 1999) are possibly of Cretaceous to Miocene age and buried by aggradational, less consolidated strata of supposedly Pliocene-Pleistocene age (Lowe and Anderson, 2002). Several unconformities separate the dipping strata and may represent phases of subglacial erosion. Dowdeswell et al. (2006) describe these SCS data from the outer shelf and upper slope close to $108^{\circ} \mathrm{W}$ (Fig. 1 ) as showing mainly aggradation on the shelf and minor progradation on the shelf edge and slope. While most of the inner shelf of Pine Island Bay is void of major sedimentary cover, as observed in seismic and acoustic subbottom profiles (Lowe and Anderson, 2003; Nitsche et al., 2013) and inferred from magnetic data (Gohl et al., 2013), a few small and shallow basins are observed close to its eastern shore (Uenzelmann-Neben et al., 2007) and close to the front of Pine Island Glacier (Kellogg and Kellogg, 1987; Nitsche et al., 2013). The western ASE shelf is separated from the eastern shelf by a bathymetric high (Nitsche et al., 2007), here named 'Bear Ridge' as it extends north from Bear Peninsula (Fig. 1). Oceanward dipping mid-shelf strata north of outcropping basement are observed in seismic data from the Dotson-Getz Trough collected in 1999 and 2006 (Wellner et al., 2001; Graham et al., 2009; Weigelt et al., 2009, 2012) and exhibit alternating sequences of low and high reflectivity, which Weigelt et al. (2009) interpret as episodes of major glacial advances and retreat in the Miocene.

Observations of sub- and proglacial bedforms in multi-beam swath bathymetry surveys, such as mega-scale lineations and grounding zone wedges, indicate that grounded ice expanded onto the middle to outer shelf during the last glacial maximum (LGM) (Lowe and Anderson, 2003; Dowdeswell et al., 2006; Evans et al., 2006; Graham et al., 2009, 2010; Larter et al., 2009; Jakobsson et al., 2012; Klages et al., 2013). The retreat of the ice sheet from the ASE shelf since the LGM is documented in both these swath-bathymetric records and sedimentary facies sequences recovered in cores (Lowe and Anderson, 2002; Smith et al., 2009, 2011; Hillenbrand et al., 2010, 2013; Ehrmann et al., 2011; Jakobsson et al., 2011; Kirshner et al., 2012; Nitsche et al., 2013). According to these studies, most of the grounded ice had retreated to the inner shelf already by the early Holocene.

To date, no core records of the stratigraphic composition and chronology of the major depositional sequences on the ASE continental shelf and slope exist. Onshore outcrops on islands, coastal cliffs and nunataks above the ice sheet in the ASE consist entirely of Mesozoic and Permian granitoids, gneisses and volcanics as well as Cenozoic volcanic rocks (e.g., Pankhurst et al., 1993, 1998; Mukasa and Dalziel, 2000; Rocchi et al., 2006; LeMasurier, 2008; Kipf et al., 2012). Although predominantly unconsolidated subglacial and glacimarine sediments on the shelf have been sampled by shallow sediment coring and grab sampling, drilling of more consolidated strata has not been attempted yet.

\section{Data acquisition and processing}

The database of SCS and MCS records from the shelf and slope of the ASE (Fig. 1) used for this study was acquired during five ship expeditions from 1994 to 2010. The first MCS data were collected from the outer shelf, slope and rise during RV Polarstern expedition ANT-XI/3 in 1994 and described in Nitsche et al. (1997, 2000). Wellner et al. (2001), Lowe and Anderson (2002, 2003) and Dowdeswell et al. (2006) described SCS datasets collected along Pine Island Trough and the Dotson-Getz Trough during RV Nathaniel B. Palmer cruise NBP9902 in 1999. More SCS data were collected on the outer shelf and the middle shelf of the western ASE during RRS James Clark Ross cruise JR141 in early 2006 (Larter et al., 2007; Graham et al., 2009), followed by MCS data recorded on RV Polarstern cruise ANT-XXIII/4 in the same season of 2006 (Gohl, 2007; Uenzelmann-Neben et al., 2007; Weigelt et al., $2009,2012)$. Due to unusually favorable sea-ice conditions in the season of early 2010, we were able to acquire more than $3500 \mathrm{~km}$ of MCS data from the middle to outer shelf, the slope and the continental rise of the Amundsen Sea during RV Polarstern expedition ANT-XXVI/3 (Gohl, 2010). The shelf profiles targeted the strata along the main axes of the Dotson-Getz Trough, the Pine Island Trough and the Abbot Trough, which is a glacial trough extending NNE-wards offshore from the western end of the Abbot Ice Shelf (Fig. 1), with some profiles crossing the troughs, inter-ice stream ridges between the troughs and tributaries feeding into the main troughs on the inner shelf or branching off them on the outer shelf.

Most MCS data of the 2010 expedition were collected using a $3000 \mathrm{~m}$ long digital solid streamer (Sercel Sentinel) with 240 channels. Only in areas with sea-ice coverage, we changed to an older $600 \mathrm{~m}$ long analogue streamer (Prakla) with 96 channels. Both streamers were towed at a nominal water depth of $10 \mathrm{~m}$. We recorded the data of both systems with a $1 \mathrm{~ms}$ sampling interval and did not apply a filter during recording with the exception of an anti-alias filter. As airgun source, we used a cluster of up to three GI-Guns (Sercel) of $150 \mathrm{in}^{3}$ volume (sum of 45 in. $^{3}$ generator and 105 in. $^{3}$ injector volumes) each, assembled underneath a steel frame to prevent ice damage, set to 'True GI-Mode' for minimizing the bubble effect, and fired at $3 \mathrm{~m}$ water depth with 195 bar operational pressure at intervals between 6 and 12 s. Due to an unsolved permitting issue with the German Federal Environment Agency, we had to refrain from using airguns of larger volumes that would have been necessary in order to obtain reflections from the basement in large parts of the middle to outer shelf and slope. In order to obtain better P-wave velocities from the shelf sedimentary rocks, we deployed six ocean-bottom seismometers (OBS) along the east-west aligned profile AWI-20100100/AWI-20100133 (Fig. 1) over the middle to outer shelf of the eastern ASE. The OBS systems recorded the GI-Gun shots fired every full minute. A summary of the acquisition instruments as well as the recording and data processing 
parameters of all seismic surveys of the ASE shelf and slope is given in Tab. S1 of the electronic supplement.

Standard data processing was initially applied to all seismic reflection records of the 2010 expedition (Tab. S1). The presence of over-compacted sediments (glacial tills) close to the seafloor is typical for polar continental shelves and, consequently, seafloor multiples of particularly large amplitudes are present throughout all seismic profiles. We applied various processing strategies to suppress seafloor multiples as much as possible, which included filtering in the frequency-wave number $(\mathrm{f}-\mathrm{k})$ domain or through a Radon transform $(\tau-\mathrm{p}$ domain). In case of good signal-to-noise ratios of the data in regular time-distance $(\mathrm{t}-\mathrm{x})$ domain, multiples were suppressed to a large degree, improving the appearance of primary reflections. In areas of low signal-to-noise ratios, and for data recorded with the short streamer, the suppression results are rather meager. A particular problem affects profiles that cross shallow parts of the outer shelf, e.g. profile AWI-20100132. Here, numerous icebergs plowed deeply into the seafloor (Evans et al., 2006; Graham et al., 2010). Such furrows generate large amplitude diffractions in the seismic wave-field and attenuate the deeply penetrating energy, in particular at the higher frequency band emitted by GI-Guns. They also aggravate attempts to remove seafloor multiples because the diffractive energy also reverberates as part of the multiple reflection signal. A configuration of airguns with larger volumes and, thus, a lower mean frequency, probably would have enabled a penetration of primary energy down to basement depths even in shelf areas where sedimentary strata are thickest. Numerous seismic profiles have data gaps due to shut-downs of the airgun sources when marine mammals were observed.

\section{Seismic characterization and horizon stratigraphy}

Given the absence of physical properties data for ASE shelf sediments measured on long drill cores or determined by borehole logging, our interpretation of seismic facies has to rely exclusively on the observation of seismic horizon analysis and reflection characteristics. A comparison to interpreted seismic sections and drill-hole controlled seismostratigraphy from other Antarctic continental shelves - mainly the Ross Sea shelf - is used to aid in our seismic profile characterization and our assignment of ages to the seismostratigraphic units observed on the ASE shelf. The main observational parameters in our analysis include (1) continuity of seismic reflectors, (2) distribution of relative reflection amplitudes, (3) stratigraphic and structural seismic layer boundaries (discontinuities, faults, downlapping, onlapping), (4) geometry of reflectors (horizontal, disturbed, undisturbed, folded, faulted, inclined/dipping), and (5) internal acoustic structure of seismic units (transparent, stratified).

We conduct our analysis beginning in the western ASE and progressively move eastward to the eastern embayment, thereby proceeding from the inner to outer shelf and slope in each region (Fig. 1). Emphasis is placed on profiles parallel and perpendicular to the main paleo-ice stream troughs in order to obtain an indication for structural trends and true dips. Up to six major sedimentary units (ASS-1 to ASS-6) and five dominant erosional unconformities (ASS-u1 to ASS-u5) can be identified for most of the ASE shelf from bottom to top.

\subsection{Western ASE shelf}

A transect of combined MCS and SCS profiles AWI-20100119 and BAS056-S111 (Fig. 2) follows the Dotson-Getz Trough from the inner to outer shelf and slope. It shows reflection characteristics representing the main depositional sequences along this trough, although the outer shelf profile had to deviate from the trough axis due to thick sea-ice cover. Oceanward dipping strata overlying acoustic basement that were previously recorded in profiles at the inner-to-middle shelf transition (Graham et al., 2009; Weigelt et al., 2009) continue seaward across the middle shelf. In the section extending from outcropping basement to about $73^{\circ} \mathrm{S}$ (shot-points 6700 to 4000 of BAS056-S111), the reflector sequences are continuous, highly stratified, of medium to high amplitudes, and dip between $4.2^{\circ}$ and $2.0^{\circ}$ at the inner to mid-shelf transition (Fig. 2). ASS-u1 marks an unconformity between 70 and 200 ms two-way travel-time (TWT) above the northward dipping basement. Deformation from faulting and folding appears locally deeper than $1.1 \mathrm{~s}$ TWT at shot-points 4200 and 5400 of BAS056-S111 (Fig. 2). The inclination of the strata decreases to $1.0-0.5^{\circ}$ on the middle shelf within sequence ASS-3. ASS-3 and younger sequences exhibit more variable, less laminated seismic facies than the underlying strata and display alternating zones of strong and poor reflectivity, which Weigelt et al. (2009) also observed in other profiles from the ASE mid-shelf (Figs. S1-S3 in supplementary material). A series of short unconformities and erosional truncations affects ASS-3 and all younger sequences. The major unconformities are annotated with ASS-u3 and ASS-u4 (Fig. 2). The outer shelf northwest of about $72^{\circ} 40^{\prime} \mathrm{S}$ (CDP 3000 of AWI-20100119) is dominated by strong progradation towards the shelf break. The lowermost prograding sequences downlap onto the older strata, and downlapping also characterizes the younger prograding units. A major erosional unconformity, ASS-u5, truncates most of the dipping sequences beneath horizontally stratified, undisturbed deposits thinning from the topmost $0.2 \mathrm{~s}$ TWT on the outer shelf to less than $0.05 \mathrm{~s}$ TWT on the middle shelf. Two large grounding zone wedges (GZW) observed in the topmost sequence on the middle shelf correlate with seaward-inclined ramps observed on parallel bathymetric profiles (Larter et al., 2009) and document temporary stillstands of grounding line retreat since the LGM (e.g. Alley et al., 1989; Larter and Vanneste, 1995; Howat and Domack, 2003; Graham et al., 2009, 2010).

\subsection{Central ASE shelf}

Profile AWI-20100139 (Fig. 3) follows the outer Pine Island Trough West (PITW), which branches off westward from the main Pine Island Trough (Evans et al., 2006). The lowermost sequence overlying the acoustic basement consists of semi-continuous reflectors between 3.2 and $4.4 \mathrm{~s}$ TWT that rise northward from the middle shelf to the shelf edge. We interpret this thin unit as partially stratified sedimentary sequence (ASS-1) lying on top of the upward tilted basement surface with regionally concordant dip and, thus, being of pre-breakup age. Basement reflections are rather subtle in terms of amplitude and continuity, possibly due to minor acoustic impedance contrasts between crystalline bedrock and the highly compacted and indurated sedimentary rocks of units ASS-1. A thick sequence of sedimentary strata (ASS-2) downlaps onto unconformity ASSu-1, which truncates these oldest sedimentary rocks. The top of unit ASS-2 is locally truncated by unconformity ASSu-2 onto which another stratified set of oceanward inclined reflectors (ASS-3) downlaps. ASS-3 is erosionally truncated by unconformity ASSu-3 that is overlain by unit ASS-4. This sequence of sedimentary strata dips oceanward from the mid-shelf. Unconformity ASSu-4 truncates unit ASS-4 and is overlain by an up to $1.5 \mathrm{~km}$ (1.3 s TWT) thick sequence of horizontal strata of varying reflection characteristics. We distinguish various zones of strong reflections alternating with reflection-poor zones within this unit, separated by continuous horizons of relatively large amplitude. These high-amplitude horizons exhibit locally restricted unconformities, but it remains unclear from the data, whether these unconformities indicate any significant shift in deposition and/or age. The uppermost sequence ASS-6 on top of unconformity ASSu- 5 can be clearly distinguished from the sequences below by its almost transparent reflection character in the MCS data. Northward of CDP 3000 (Fig. 3), the sediment strata of units ASS-5 and ASS-6 form a progradational wedge building the outermost $25 \mathrm{~km}$ of the modern top shelf. However, it is interesting to note that these prograding strata directly downlap onto unconformity ASSu-4. 


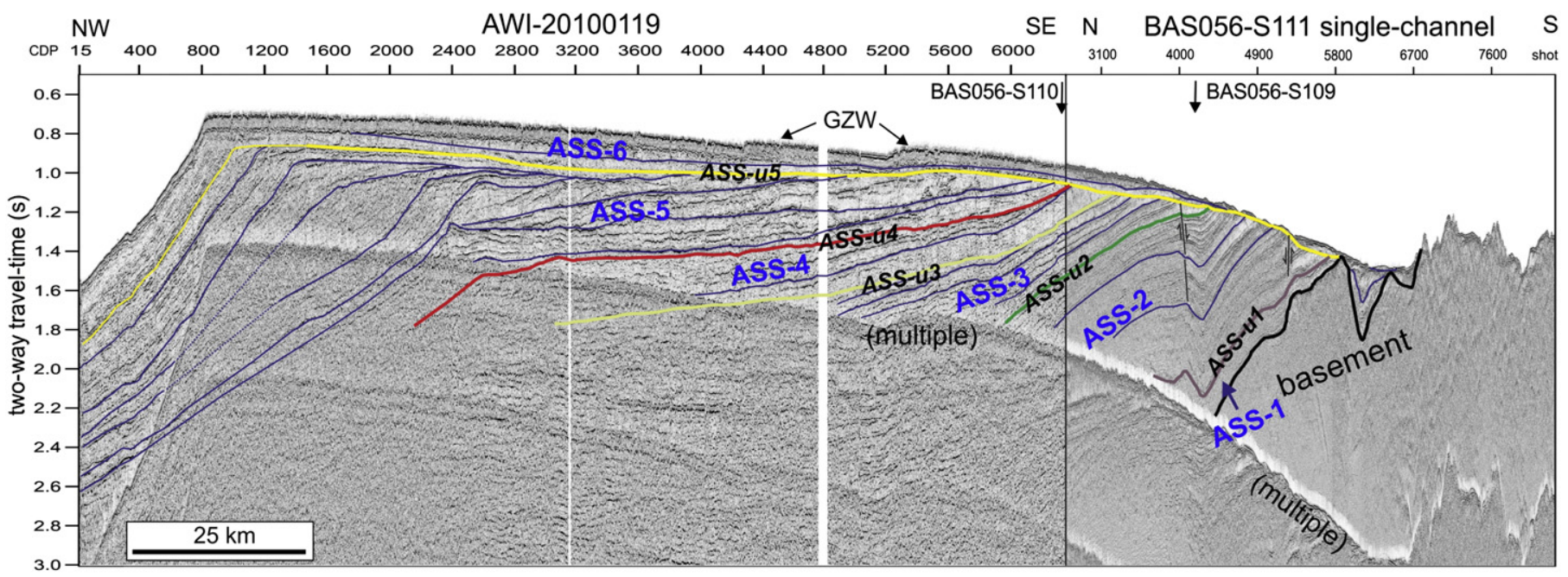

Fig. 2. Composite of seismic profiles BAS056-S111 and AWI-20100119 following the Dotson-Getz Trough of the western ASE shelf and across the upper slope. Main unconformities ASS-u1 to ASS-u5 separating the major seismostratigraphic units ASS-1 to ASS-6 are marked and annotated. Other dominant reflectors within these units are highlighted by the dark blue lines. Note normal faults within folded strata on the inner shelf. Black arrows indicate crossing seismic lines. GZW stands for grounding zone wedge. Description of seismic horizons and reflection characteristics is in the text. See profile locations in Fig. 1. (For interpretation of the references to color in this figure legend, the reader is referred to the web version of this article.)

Within the upper sequences of unit ASS-5 (Fig. 3), two lens-shaped features are observed that have a geometry typical for GZWs with a steeper ice-distal (lee) side and a more attenuated ice-proximal (stoss) side. We interpret these features as buried grounding zone wedges (bGZW) (Dowdeswell and Fugelli, 2012). bGZWs were formed on the shelf by retreating grounded ice sheets when the retreat of the grounding zone came to a temporary halt (e.g. Larter and Vanneste, 1995; Dowdeswell and Fugelli, 2012). bGZW 1 shows at 1.25 s TWT near CDP 500, and the stratigraphically higher bGZW 2 can be observed at $1.20 \mathrm{~s}$ TWT near CDP 2300. The surfical GZW at CDP 1400 is identified as an exposed bedform feature of uppermost unit ASS-6. The two crossing SCS lines BAS056-S112 and BAS056-S113 (R. Larter, unpublished data) show buried and exposed grounding-zone wedges of similar shape and lack of internal stratification within the upper part of units ASS-5 and ASS-6.

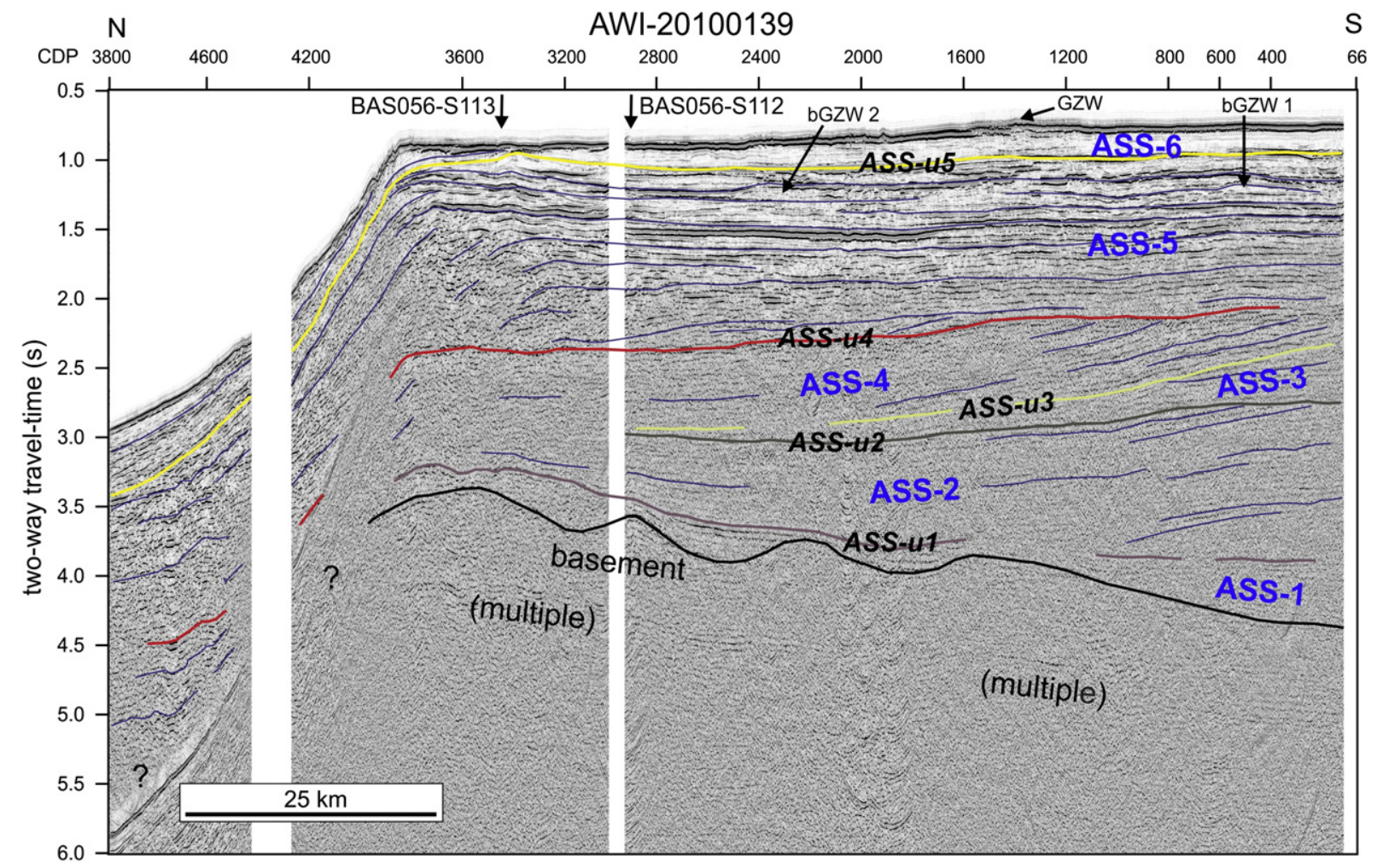

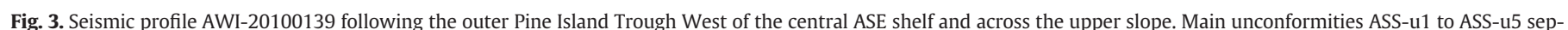

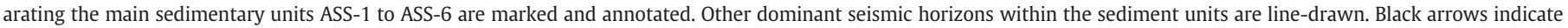

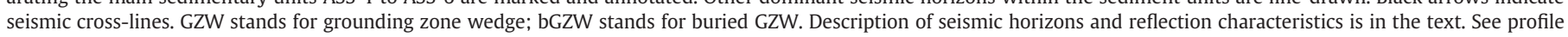
location in Fig. 1. 


\subsection{Eastern ASE shelf and Pine Island Bay}

A set of north-south trending seismic profiles and several crossing profiles cover a large part of the central Pine Island Trough from the inner shelf to its outer shelf branches. The composite MCS transect consisting of profiles AWI-20100132, AWI-20100134 and AWI20100135 (Fig. 4a) follows the western trough flank and images sequences of sedimentary strata down to maximum basement depths of about $7 \mathrm{~km}$ below seafloor on the middle shelf (using an average P-wave velocity of $3.5 \mathrm{~km} / \mathrm{s}$ for the sedimentary column). However, the relatively small airgun source and strong seafloor multiple reflections prevent unambiguous identification of a deep continuous reflector as the top of the acoustic basement. Our interpretation is derived from the observation that the lowermost northward dipping sedimentary strata downlap onto a deep-lying, discontinuous and weak reflector rising from the middle to outer shelf. We cannot entirely exclude the possibility, however, that the apparent top of the acoustic basement represents the top of compact, highly consolidated or even lithified sedimentary strata.

We observe five main unconformities in this composite profile (Fig. 4a). Lowermost unconformity ASS-u1 separates units that exhibit minor deformation but dip slightly in opposite directions underneath the inner shelf. The unit between unconformities ASS-u1 and ASS-u2 is partially deformed and disrupted by faults on the inner shelf. The strongest erosional signature characterizes unconformity ASS-u4 in the mid-shelf section of the profile, where it truncates the strata of unit ASS-4. ASS-u4 can be traced seaward to the outer shelf. There, a wedge of progradational foreset beds downlaps onto it, as observed in profile AWI-20100139 from the outer PITW (Fig. 3). The lack of progradation beneath ASS-u4 on the outer shelf indicates that it may represent the paleo-shelf seabed before grounded ice reached the outer shelf. Despite the remnants of seafloor multiple reflections at the shelf break, it is possible to trace ASS-u4 to the base of the continental slope and farther onto the continental rise where it can be correlated with the top of seismostratigraphic Unit 2 of Uenzelmann-Neben and Gohl (2012). They estimated an age of 21-14 Ma for their Unit 2 from an indirect correlation to a preglacial to glacial transitional stage with ice caps expanding onto the eastern Ross Sea shelf as observed by De Santis et al. (1999). The uppermost unconformity ASS-u5 truncates middle shelf strata down to about $400 \mathrm{~m}$ depth below seafloor and can also be traced onto the continental rise, where it corresponds to the top reflector of Unit 3 with an age of $4 \mathrm{Ma}$ (Uenzelmann-Neben and Gohl, 2012) derived from long-distance horizon correlation to DSDP Site 324 in the western Bellingshausen Sea (Tucholke et al., 1976).

The SCS profile NBP9902-11 of Lowe and Anderson (2002, 2003) (Fig. S4) follows the deepest section of the central Pine Island Trough and then crosses the outer shelf. The strata and unconformity sequence above the seafloor multiple resembles that of our composite MCS profile (Fig. 4), except that on NBP9902-11 we identify ASS-u2 with a rather large uncertainty. The strata beneath this unconformity are moderately folded and faulted, while strata above it and further seaward exhibit little evidence of deformation. ASS-u4 is the dominant unconformity and separates oceanward dipping strata from more horizontally layered sequences. The "amalgamated glacial unconformity" of Lowe and Anderson (2002) is named ASS-u5 in our analysis. Graham et al. (2010) and Jakobsson et al. (2012) identified a large GZW on the seafloor above ASS-u5 at the transition from the inner to middle shelf (Fig. S4).

MCS line AWI-20100122 (Fig. S5) follows the eastern flank of the central Pine Island Trough. Although the top of the acoustic basement north of CDP 3600 is poorly imaged, it appears that between CDP 3600 and CDP 1800 the configuration of the overlying strata (below ASSu-5) largely conforms with the undulating basement relief. Folding and faulting of the oldest sedimentary strata is clearer than in the two parallel profiles further to the west. The reflection character changes from deformed reflectors to steadily northward dipping strata in the northern part of this profile. The youngest unconformity ASS-u5 with up to $250 \mathrm{~m}$ of overlying horizontally layered strata can be traced along most of the profile.

Progradational deposits characterize the outer shelf along the eastern flank of the central Pine Island Trough as the composite of profiles AWI-20060001, -0002 and AWI-94042 (Fig. 5) reveal. The progradational wedge of the outermost shelf is overlain by an aggradational unit that is up to $460 \mathrm{~m}$ thick, as previously described by Nitsche et al. (1997). However, the new seismic profiles presented here extend further landward and reveal that the onset of oldest progradation was located at least $60 \mathrm{~km}$ south of the present shelf break above unconformity ASS-u4. The crossing, east-west striking SCS profile BAS056-S114 (Fig. S6) shows eastward prograding sequences overlain by aggradational, slightly wavy strata. The aggradational units in profiles AWI-20060001, -0002 and BAS056-S114 are up to $700 \mathrm{~m}$ thick (conversion of $0.6 \mathrm{~s}$ TWT by using a P-wave velocity of $2300 \mathrm{~m} / \mathrm{s}$ for highly consolidated sedimentary strata). Unfortunately, the use of the short streamer for the 2006 MCS surveys and numerous diffractions from iceberg scours compromised attempts to suppress seafloor multiple reflections and, thus, deeper horizons could not be imaged.

Uenzelmann-Neben et al. (2007) analyzed seismic profiles AWI20060010 and -0011 along the easternmost Pine Island Bay close to the shores of Canisteo Peninsula and King Peninsula (Fig. 1a,b). They identified up to $300 \mathrm{~m}$ thick sedimentary strata in a glacial trough extending WNW-wards from the Cosgrove Ice Shelf ('Cosgrove Trough' in Klages et al., 2013) and northward dipping and thickening strata in the NNE-ward striking Abbot paleo-ice stream trough, which is wider and deeper than the western and eastern branches of outer Pine Island Trough (Fig. 1). The new seismic profiles AWI-20100126b, -0127 and -0128 (Fig. 1) have recently revealed that the seabed underlying Abbot Trough is characterized by strong progradation and that its sedimentary architecture is controlled by various basement highs and ridges (Hochmuth and Gohl, in press).

The seismic profiles AWI-20100126a, AWI-20100121, AWI20100133 and BAS056-S114 cross the central Pine Island Trough and its eastern outer shelf branch (PITE) in an east-west direction, link the trough-parallel lines (Fig. 1) and enable a detailed spatial analysis of the seismostratigraphic units and unconformities. Profile AWI-20100126a (Fig. 6) and composite profiles AWI-20100120 and -0121 (Fig. 7) reveal a sedimentary sub-basin within the mid-shelf part of central Pine Island Trough with up to $4-4.5 \mathrm{~km}$ thick infill at about $108^{\circ} 30^{\prime} \mathrm{W}$. To the east, this sub-basin is bound by a steeply rising basement, which further ascends towards a basement high northwest of Burke Island (Fig. 6). In the central Pine Island Trough we correlated major unconformities with those observed in the trough-parallel profiles. Unconformity ASS-u1 terminates at the basement flank, while unconformity ASS-u2 can be traced along the entire profile AWI-20100126a. The major glacial unconformity ASS-u5, whose subbottom depth roughly conforms with the bathymetric incision of the central Pine Island Trough, truncates the unit ASS-3 on AWI-20100126a (Fig. 6) while ASS-u4 truncates the reflectors in unit ASS-4 farther north (Fig. 7). In general, the seismic reflectors in profile AWI-20100126a appear more irregular and chaotic within the sub-basin than outside of it. This situation contrasts with the parallel profile AWI-20100121 farther north, where the reflectors both within and outside the sub-basin are rather smooth. In profile AWI-20100133 (Fig. S7) on the outer shelf the bathymetric expression of the central Pine Island Trough is rather subdued (the total bathymetric difference along the $120 \mathrm{~km}$ long profile is just $150 \mathrm{~m}$ ) and both the seismostratographic sequences and correlated unconformities are mostly horizontal. Only ASS-u3 truncates northwestdipping older strata, and ASS-u5 truncates slightly eastward dipping reflectors. We assume that the sequences of sedimentary strata in profile AWI-20100133 rise eastwards, because near the eastern flank of PITE 


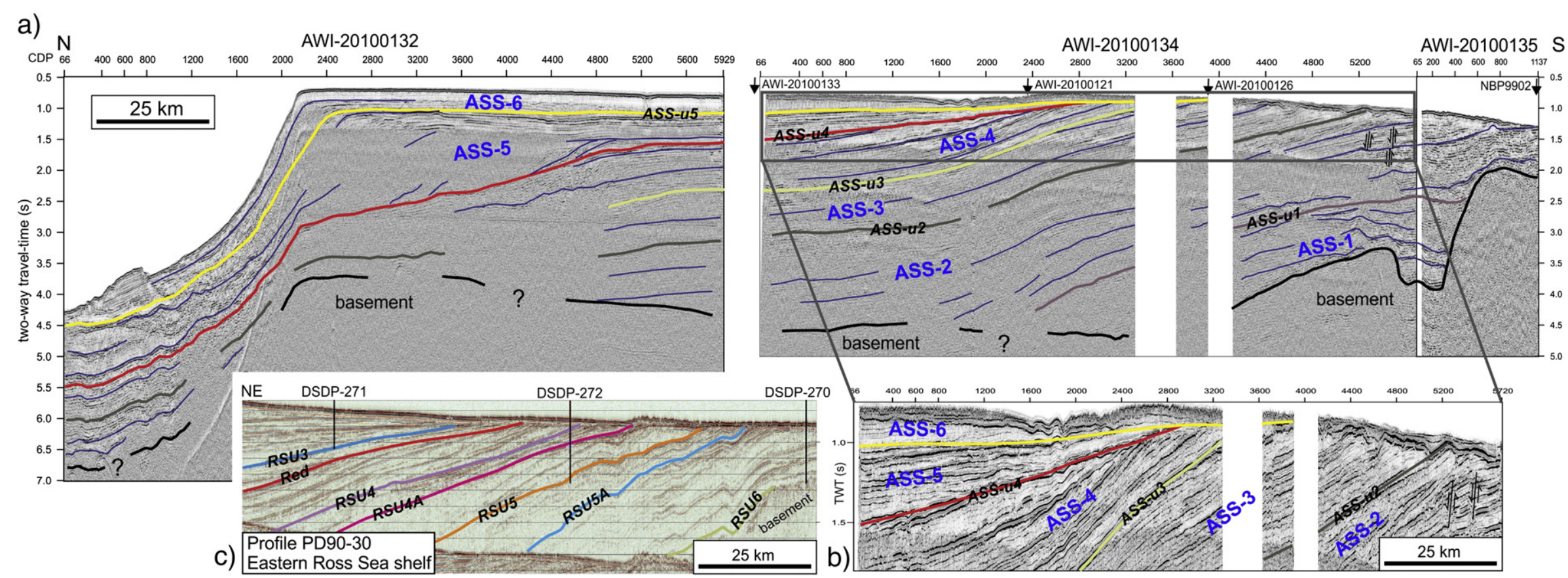

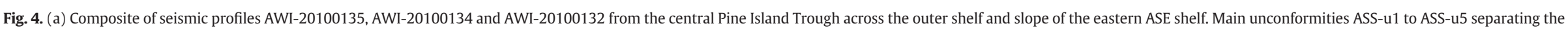

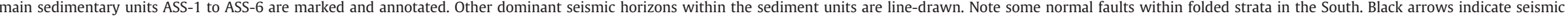

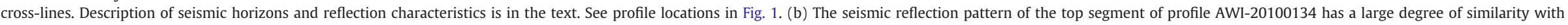

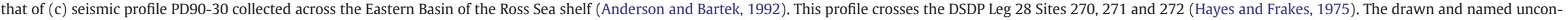
formities are from Decesari et al. (2007) and Sorlien et al. (2007). 


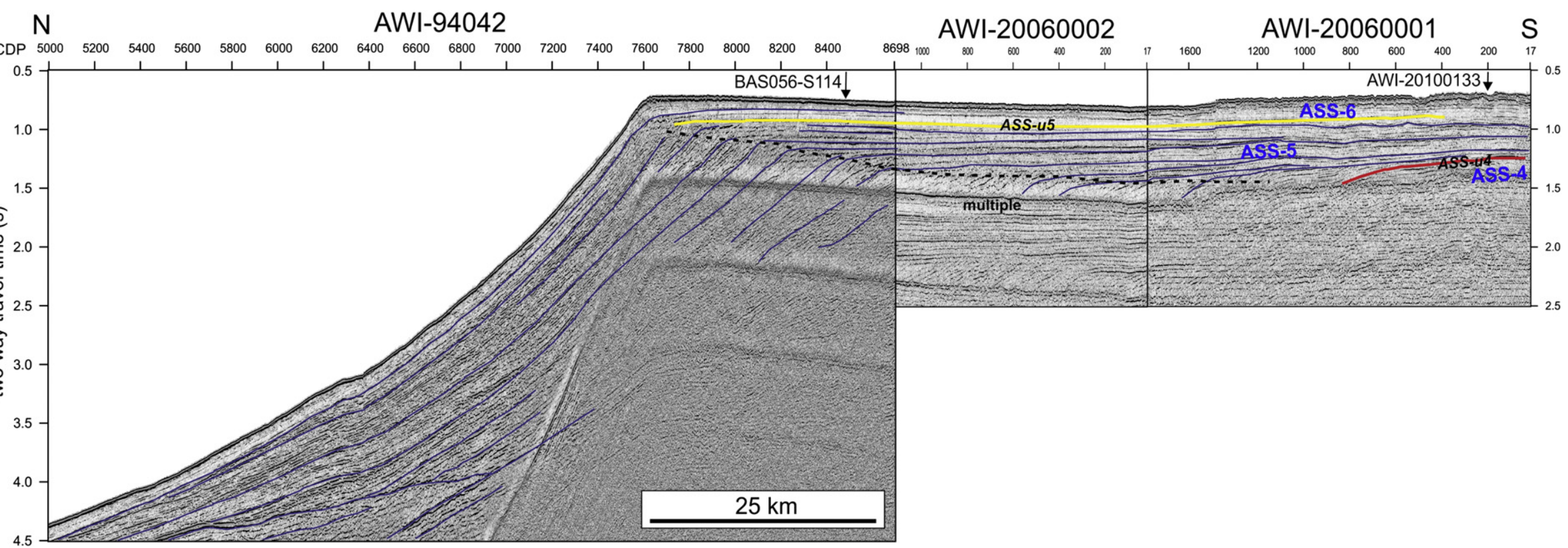

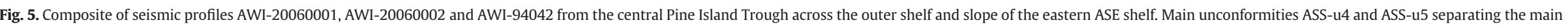

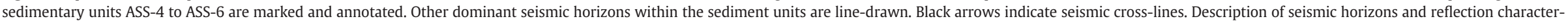
istics is in the text. See profile locations in Fig. 1. 
they overlie a basement high, which possibly extends seaward from the basement ridge north of Burke Island identified in profile AWI20100126a (Fig. 6). However, the low-fold quality of seismic profile AWI-20100133 does not reveal the top of the basement and neither does that of the crossing line AWI-20060001 (Fig. 5).

\section{Sedimentation patterns and chronological constraints}

We used the composite profiles AWI-20100132 to 20100135 (Fig. 4a) and the southernmost part of the SCS profile NBP9902-11 (Fig. S4) for a depth-converted transect from the inner to outer shelf of the eastern ASE, primarily using seismic velocities we derived from a velocity-depth model from seismic refraction phases recorded by the OBS systems along profile AWI-20100100/AWI-20100133 (Fig. 8). Our P-wave velocities in this seismic refraction model range from $2.0 \mathrm{~km} / \mathrm{s}$ for sediments near the seafloor to $4.2 \mathrm{~km} / \mathrm{s}$ for sedimentary rocks at $3.7 \mathrm{~km}$ depth below seafloor (b.sf.). The velocitydepth distribution is almost uniform along the east-west oriented profile. Compared to sedimentary rock velocities of other glaciated shelves (e.g., Cochrane et al., 1995; Larter et al., 1997), the relatively high velocities of the upper sediments are characteristic for overcompaction resulting from the pressure exercised by the repeated overriding by an ice sheet. A P-wave velocity of ca. $1750 \mathrm{~m} / \mathrm{s}$ measured on a subglacial till recovered within $1 \mathrm{~m}$ b.sf. in the eastern ASE (Klages et al., 2013) is consistent with these high sediment velocities near the seafloor. As refraction arrivals from deeper seated sedimentary sequences were not recorded due to the small airgun configuration, we used a velocity of $4.5 \mathrm{~km} / \mathrm{s}$ for sedimentary rocks deeper than $4 \mathrm{~km}$ b.sf.

The depth-converted transect (Fig. 9) follows along the western flank of the central Pine Island Trough. It clearly illustrates a large basin infill between the basement high underneath the Eastern Outer Bank and the basement cropping out on the inner shelf, with sub-horizontal sedimentary strata lapping onto the basement flanks. We assume that pre- and syn-rift sediments filled the deeper part of the basin, which likely developed as part of the rifting process before and during the breakup between the Chatham Rise and West Antarctica. Post-rift sediments were deposited on top of the Eastern Outer Bank basement block. The outer shelf is characterized by considerable progradation of sedimentary strata that downlap onto an at least $1300 \mathrm{~m}$ thick sequence of aggraded sedimentary strata deposited over the basement high. Similar to observations on other Antarctic shelves (e.g., Cooper et al., 1991; Anderson et al., 1992; Eittreim et al., 1995; De Santis et al., 1999), the onset of progradation may be interpreted as the beginning of major subglacial sediment transport across the entire ASE shelf by an advanced grounded ice sheet. Although ASS-u4 is observed as a major glacial erosional unconformity, ASS-u3 is likely to mark the beginning of the pre-glacial to glacial transition with first glacier advances onto the inner to middle shelf. Taking into account the depth difference between ASS-u3 and ASS-u1, we conclude that at least $4 \mathrm{~km}$ of pre-glacial strata must have been eroded from the present inner shelf and coastal hinterland since the onset of grounded ice-sheet advance across the entire ASE shelf.

We attempt to constrain a chronology for the seismostratigraphic units on the ASE shelf by comparing their reflection characteristics with those of other Antarctic shelves, for which chrono-stratigraphic models were derived from drill cores and borehole records. The best analogue for the ASE shelf appears to be the Eastern Basin of the Ross Sea shelf, because both regions share a similar continental breakup history and glacial sedimentation processes by the same ice sheet. Seismic profiles BGR80-07 and PD90-30 (Cooper et al., 1991; Anderson and Bartek, 1992; De Santis et al., 1995, 1999; Brancolini et al., 1997; Anderson, 1999; Chow and Bart, 2003) cross DSDP Sites 270, 272 and 271 and show a striking similarity in the pattern and sequence of seismic units and unconformities with those of our transect AWI-20100132 to -0135 (Fig. 4b,c). In particular, the major glacial unconformity ASS-u4 cuts strata with a high truncation angle similar to unconformity RSU3 in the Ross Sea. By assuming that this unconformity represents the same major glacial advance period, our ASE shelf unconformities (from bottom to top) ASS-u2, ASS-u3, ASS-u4 and ASS-u5 consequently may correspond to the Ross Sea unconformities (from bottom to top) RSU5, RSU4/RSU4A, RSU3 and RSU2 (Cooper et al., 1991; De Santis et al., 1995, 1999; Anderson, 1999; Decesari et al., 2007; Sorlien et al., 2007; C. Sorlien, pers. comm.), respectively. The unconformity RSU2 correlates to the Ri unconformity in the Victoria Land Basin and was drilled in the ANDRILL cores (Fielding et al., 2008; Wilson et al., 2012). Only the oldest unconformity ASS-u1 does not correlate well with RSU6. By adopting the ages of the correlation chart for the Ross Sea shelf by De Santis et al. (1999), we estimate a preliminary age model for the ASE shelf sediments (Fig. 10).

\section{Discussion of a sedimentation model and implications for ice sheet dynamics}

As demonstrated by geophysical and petrological/geochemical data, the continental margin of the Amundsen Sea and the Marie Byrd Land/ Thurston Island blocks was formed by rifting prior to and during the breakup of New Zealand's Chatham Rise and Campbell Plateau (Larter et al., 2002; Eagles et al., 2004; Kipf et al., 2012; Wobbe et al., 2012; Gohl et al., 2013) (Fig. 9). Gravity and magnetic anomalies (Gohl et al., 2007,2013 ) coincide with the location of a basement ridge underneath the Eastern and Western Outer Bank (Figs. 1, 4, 9), indicating that this ridge may represent the remnant of a crustal block that rifted a distance apart from Marie Byrd Land before breakup occurred north of it at 90-85 Ma. Although the onlapping of the sedimentary sequences of unit ASS-1 onto the Outer Bank basement ridge indicates that syn-rift sediments had filled most of the basin south of it, possibly in a back-arc setting, the southernmost strata show the most pronounced deformation. They may represent pre-rift sediments that were folded during the convergent plate boundary phase before or during the collision of Hikurangi Plateau with Chatham Rise at about 105-100 Ma (Davy et al., 2008). The sparse observation of horizons below ASS-u1 does not allow the identification of any faulting in the sediments and basement that would further support this interpretation. However, it is possible that ASS-u1 ( 105-90 Ma?) marks the transition from a convergent to a divergent margin when the basin subsided at a different rate (Fig. 9). Unit ASS-2, which has an estimated Late Cretaceous age, was deposited unconformably on sediments of the convergent plate boundary phase. Passive margin shelf deposition was dominated by sedimentation of horizontal strata, continued without any clear hiatus into Oligocene times and buried the Outer Bank basement ridge. Folding and faulting observed in the southernmost sections of unit ASS-2, in particular on the inner shelf of the western ASE transect, indicate that convergent or transpressional tectonic processes were active at least until the latest Cretaceous or into the Oligocene. This deformation may have been caused by transpressional and translateral motion of the southern Bellingshausen Plate boundary (Eagles et al., 2004; Gohl et al., 2013) and/or the West Antarctic Rift System (Müller et al., 2007; Jordan et al., 2010) (Fig. 9).

Unconformity ASS-u2 ( 21-19 Ma?) marks a very subtle and gradual change in depositional processes towards those dominating the formation of unit ASS-3 (Fig. 9). Decesari et al. (2007) correlated RSU5, which we compare with ASS-u2, from the eastern Ross Sea to the Victoria Land Basin where it was dated with $\sim 21 \mathrm{Ma}$ from the chronostratigraphy of CRP-1 and CRP-2/2A drill cores (Fielding et al., 2008, and references therein). ASS-3 is characterized by increasingly distinct alternations between seismically transparent and more reflective horizons. The first subglacially transported sediments reached the inner Ross Sea shelf in the Oligocene and were supplied by outlet glaciers draining local ice caps rather than an ice sheet (e.g., De Santis et al., 1999). This is also possible for the ASE, because 


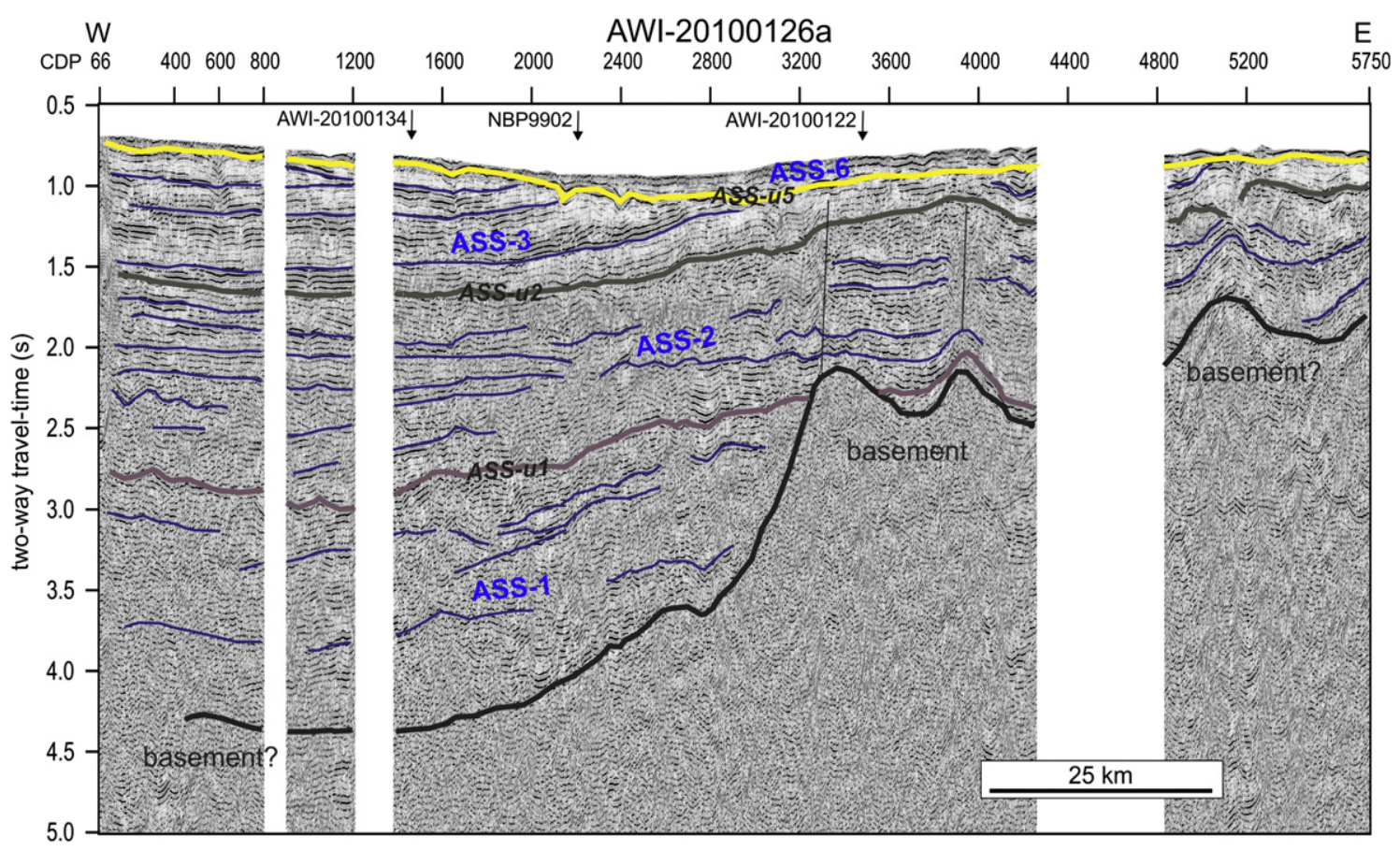

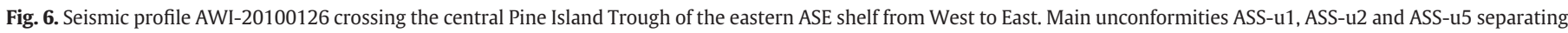

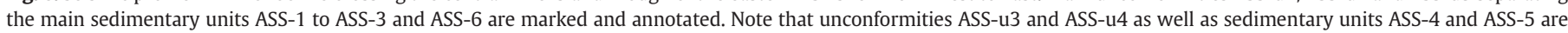

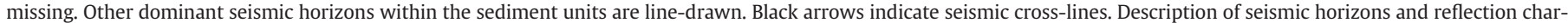
acteristics is in the text. See profile location in Fig. 1.

an elevated hinterland, in particular an uplifted central Marie Byrd Land block (LeMasurier, 2008) and the mountain ranges of Ellsworth Land, could have already in the Late Oligocene or Early Miocene provided nucleation points for such regional ice caps that modified the character of the inner to middle shelf deposition with additional supply of glacial debris. At this time, the outer shelf and continental slope were probably not yet affected by deposition of glacigenic debris. We name this period the 'pre-glacial to glacial transitional phase'. The landscape evolution of Marie Byrd Land, together with volcanic products of ice-contact eruptions and the composition of lake sediments, indicate that ice caps had affected the ASE hinterland possibly as early as in Oligocene times (Rocchi et al., 2006).

First advance of grounded ice onto the middle ASE shelf is evident from erosional unconformity ASS-u3 (Fig. 9) and seems to have occurred as early as $14 \mathrm{Ma}$, if the analogue to the similar Ross Sea event is applicable. Progradation within unit ASS-4 is not observed suggesting that grounded ice did not advance to the outer shelf.

The largest erosional event by grounded ice advancing to the outer shelf is marked by the dominant unconformity ASS-u4 ( 12-10 Ma) (Fig. 9). Similar to unconformity RSU3 on the Ross Sea shelf, it truncates older middle shelf strata obliquely and forms the basal surface on which major progradational sequences build the upper $40-70 \%$ of the outer shelf. The numerous subordinate and shorter unconformities within units ASS-5 to ASS-6 (e.g., Figs. 2 and S4) indicate frequent advance and retreat episodes of grounded ice beginning in the Late Miocene and continuing to the Pliocene and Pleistocene according to our age model. Buried grounding zone wedges in the upper sequences of unit ASS-5 (Fig. 3) suggest ice sheet advance to the outer shelf in the early Pliocene. These bGZWs could only survive later overriding by grounded ice, if thick (glaci-)marine sediments were deposited on top of them during times when the grounding line was located farther landward (i.e. during long interglacial periods). The prolonged accumulation of pelagic sediment resulted in the observed burial of the grounding zone wedges, which prevented them from being eroded by subsequent grounding line advances during later glacial periods. Their preservation on the ASE shelf may, therefore, indicate an extended warm period with a retreated ice sheet and polythermal glacial activity resulting in high subglacial erosion and high offshore sedimentation rates. With the existing sparse data, it remains speculative whether this period was characterized by an entirely ice-free ASE shelf and a WAIS significantly smaller than today, which would be consistent with the results of ice sheet modeling (Pollard and DeConto, 2009) and evidence for prolonged (seasonal) open-marine conditions during the early Pliocene ( 5-3 Ma) at core site ANDRILL AND-1B from the Ross Sea shelf (Naish et al., 2009). However, we argue that a sub-ice shelf situation proximal to a grounding line cannot be sustained over long periods, because this would make occasional advances of the grounding zone with erosion of the GZWs very likely. More importantly, a sub-ice shelf environment distal from the grounding line or a setting under perennial sea-ice coverage would imply low sedimentation rates that range in modern Antarctica usually in the order of just $1-10 \mathrm{~cm} / \mathrm{kyr}$ (e.g., Domack et al., 2005; Hemer et al., 2007; McKay et al., 2008). Given the fact that the crest-base height difference of the bGZWs is approximately $50-60 \mathrm{~m}$ and assuming that they were buried under sustained coverage with floating ice at sedimentation rates of $25-100 \mathrm{~cm} / \mathrm{kyr}$, i.e. the highest sub-ice shelf sedimentation rates reported for Antarctica (Pudsey and Evans, 2001), the observed GZW burial must have taken at least 55$225 \mathrm{kyr}$. We consider this scenario to be very unlikely and, therefore, suggest GZW burial in a seasonal to permanently open-marine setting with high plankton productivity far away from the grounding line, which must have retreated at least onto the middle or inner shelf.

Cooling in the Late Pliocene, as documented for the Ross Sea sector (McKay et al., 2012), allowed grounded ice to advance across the middle and outer shelf of the ASE again, which is evident from the truncation of strata in unit ASS-5 and younger units on the inner to middle shelf (unconformity ASS-u5) (Fig. 9). Progradation of unit ASS- 6 continued the oceanward growth of the outer shelf. Numerous unconformities and surficial GZWs within ASS-6 indicate that grounded ice repeatedly advanced to the outer shelf during late Pleistocene glacial periods and that subsequent retreat often was episodic. 


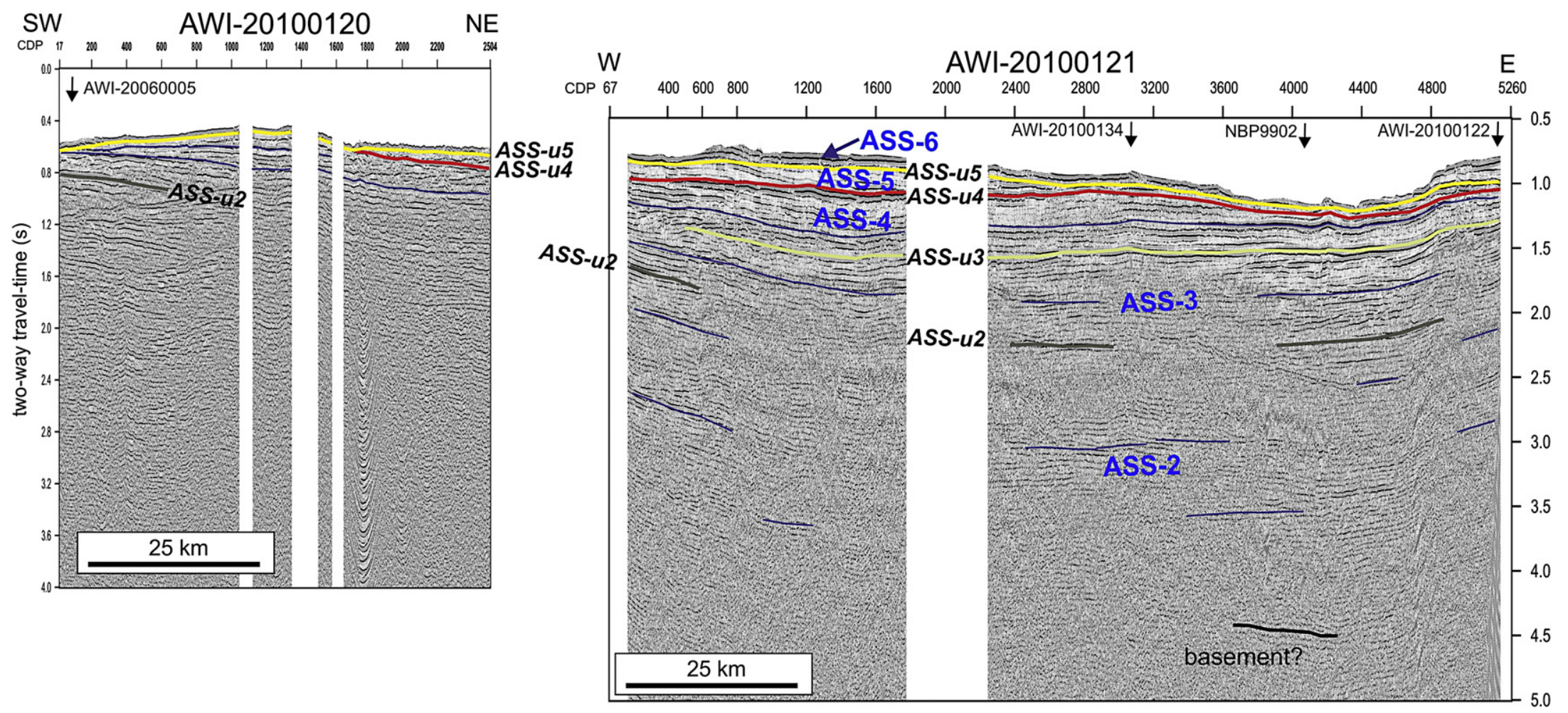

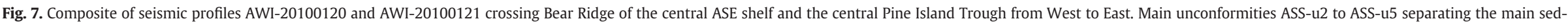

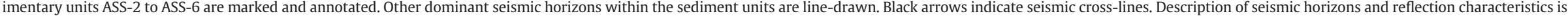
in the text. See profile location in Fig. 1. 
a)

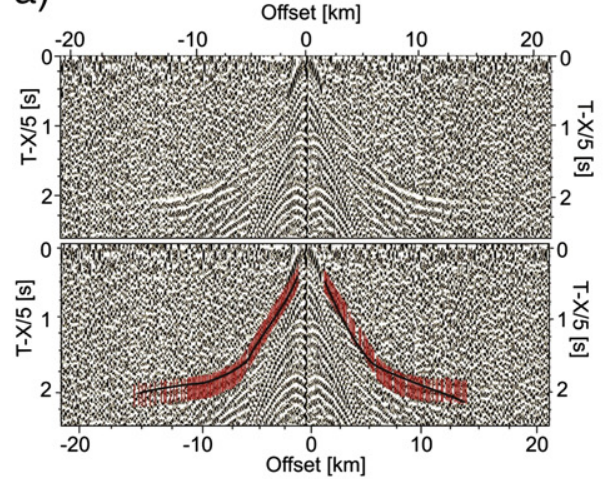

b)

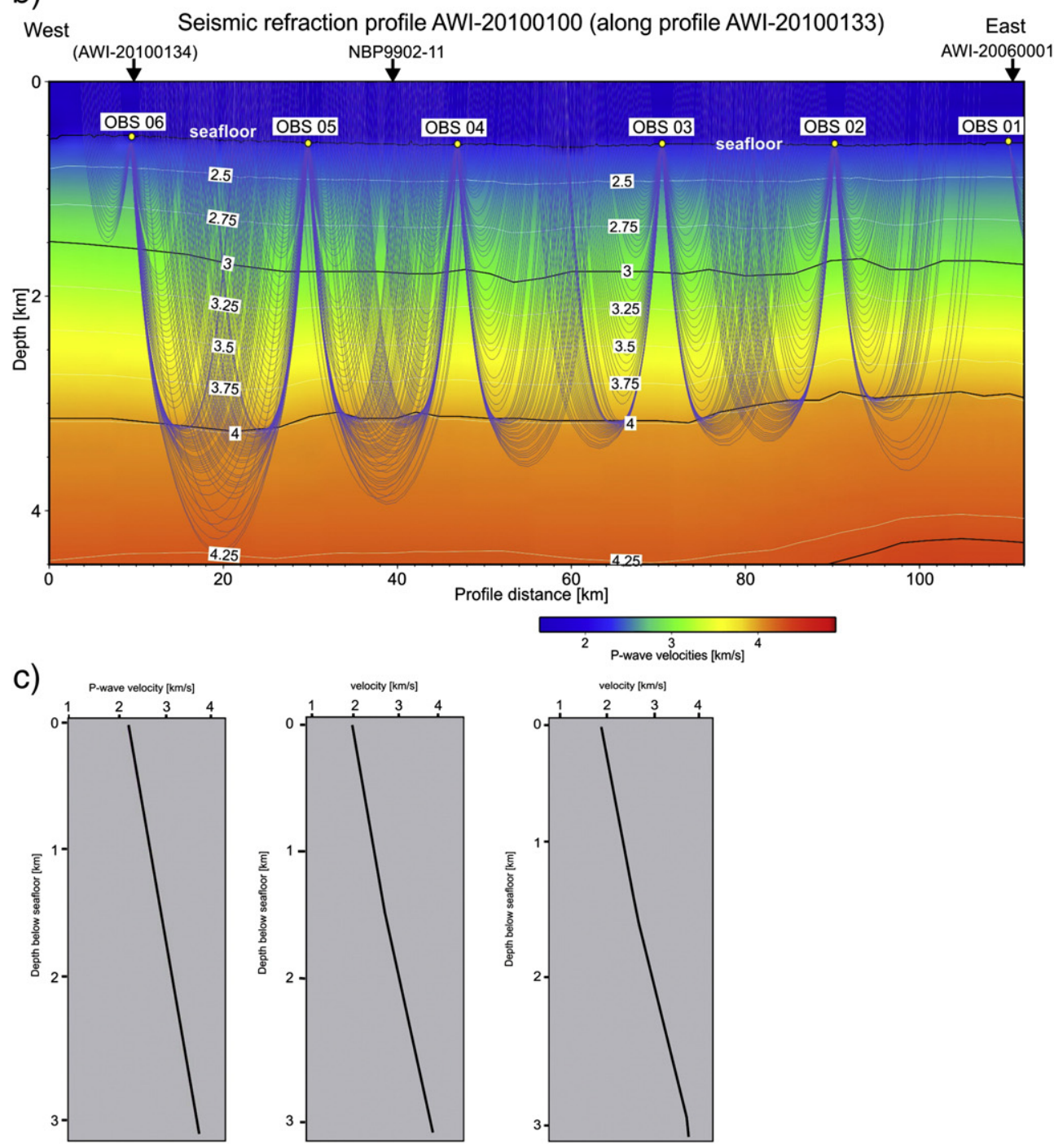

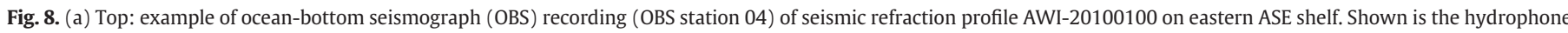

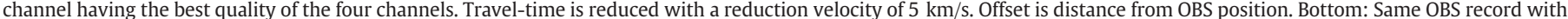

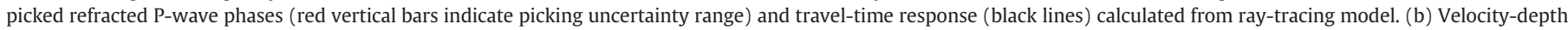

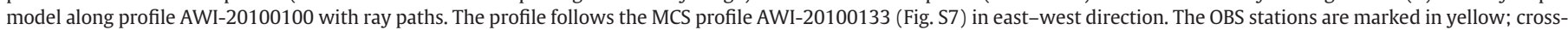

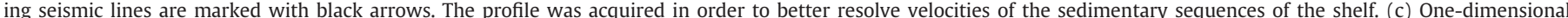

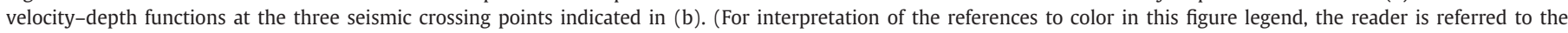
web version of this article.)

The east-west orientated seismic profiles on the middle shelf of the eastern ASE clearly illustrate a sub-basin with its long axis striking NNE-SSW (Fig. 11). While its gentle western flank peters out towards Bear Ridge, its sickle-shaped, steeper eastern flank is bordered by a basement high that underlies most of the easternmost shelf, i.e. from the islands in eastern Pine Island Bay to a ridge underlying Burke Island and extending further north. The seismic expression of this sub-basin coincides with a large area of smooth magnetic anomaly lows (Gohl et 


\section{North}

a)

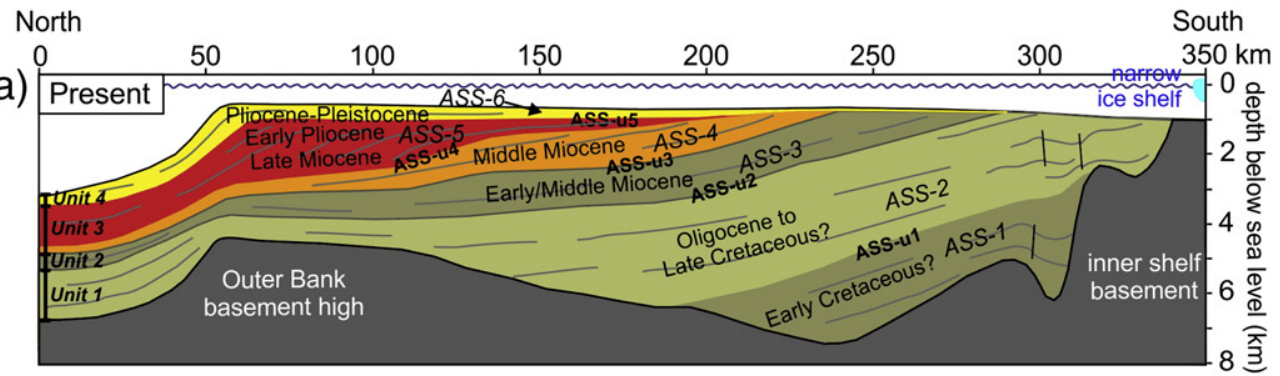

South

$350 \mathrm{~km}$

b) Pliocene

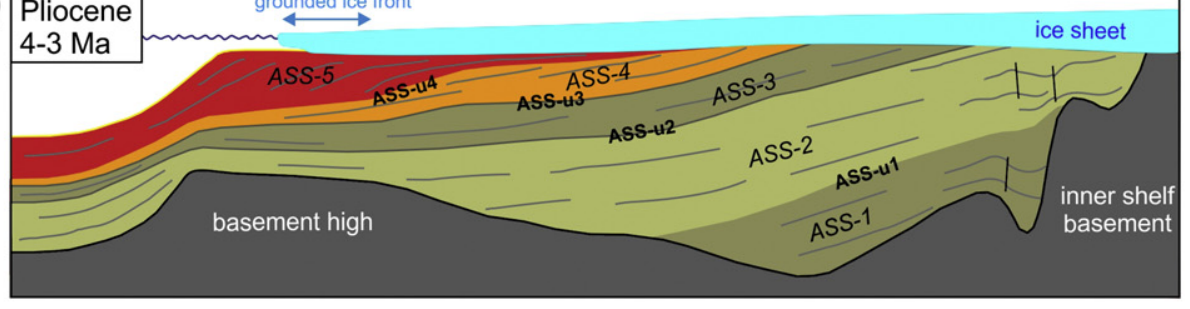

c) Middle to Late Miocene

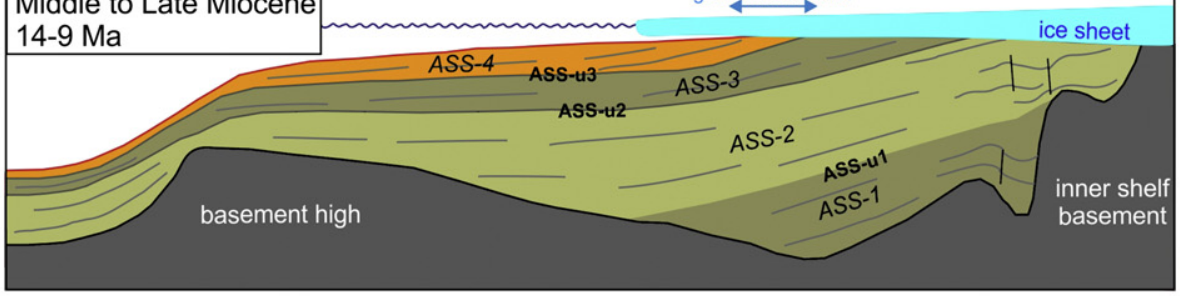

d) Middle Miocene

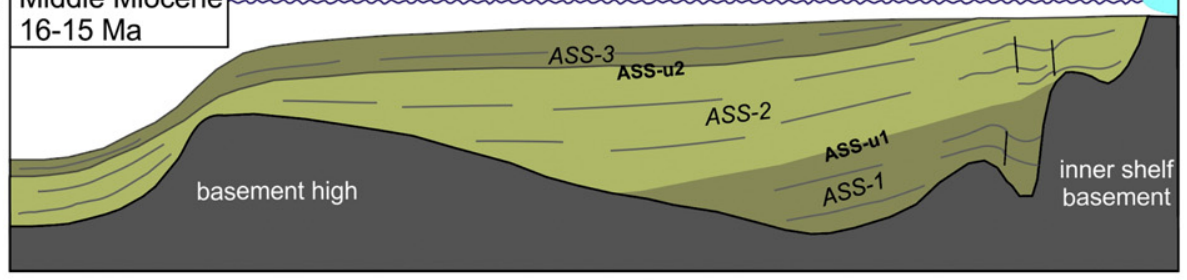

e) Early Miocene 21-19 Ma

Bellingshausen Plate motion 21-19 Ma and/or WARS tectonics
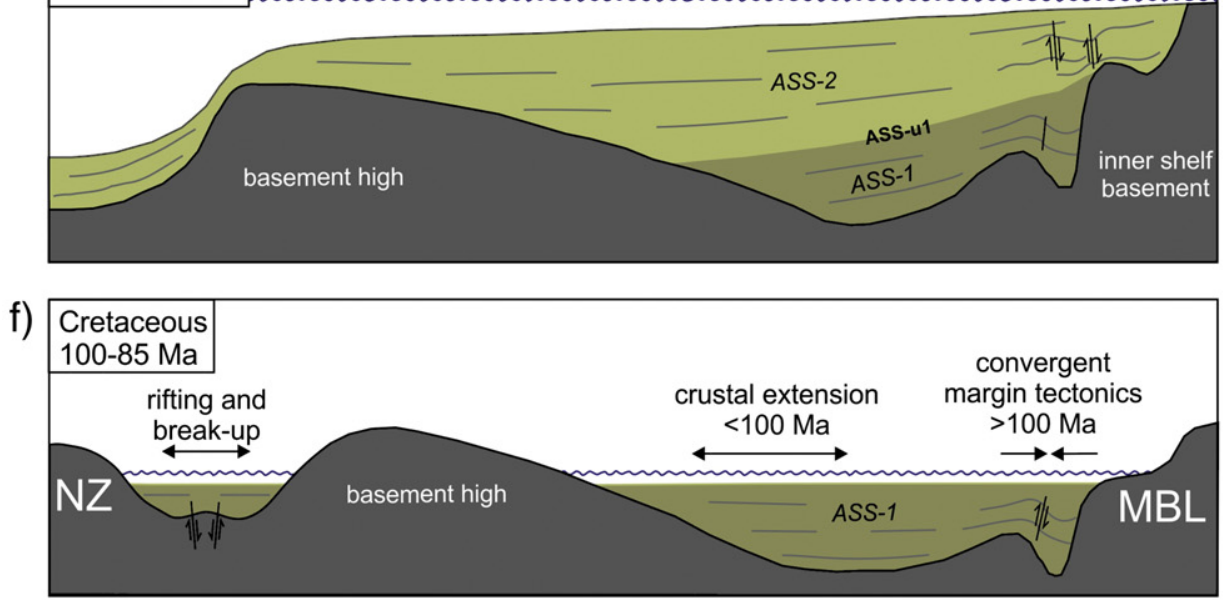

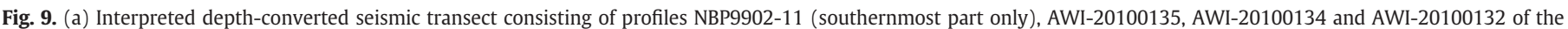

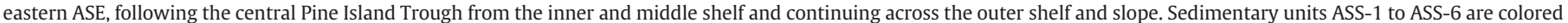

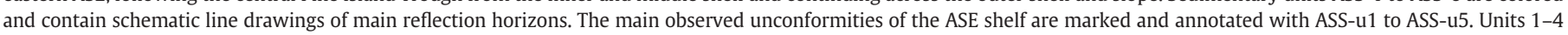

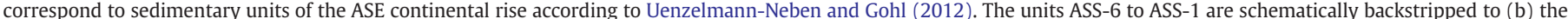

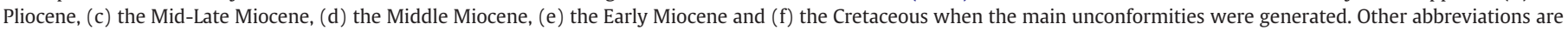
NZ for New Zealand, MBL for Marie Byrd Land and WARS for West Antarctic Rift System. This basin development model is explained in the text. 


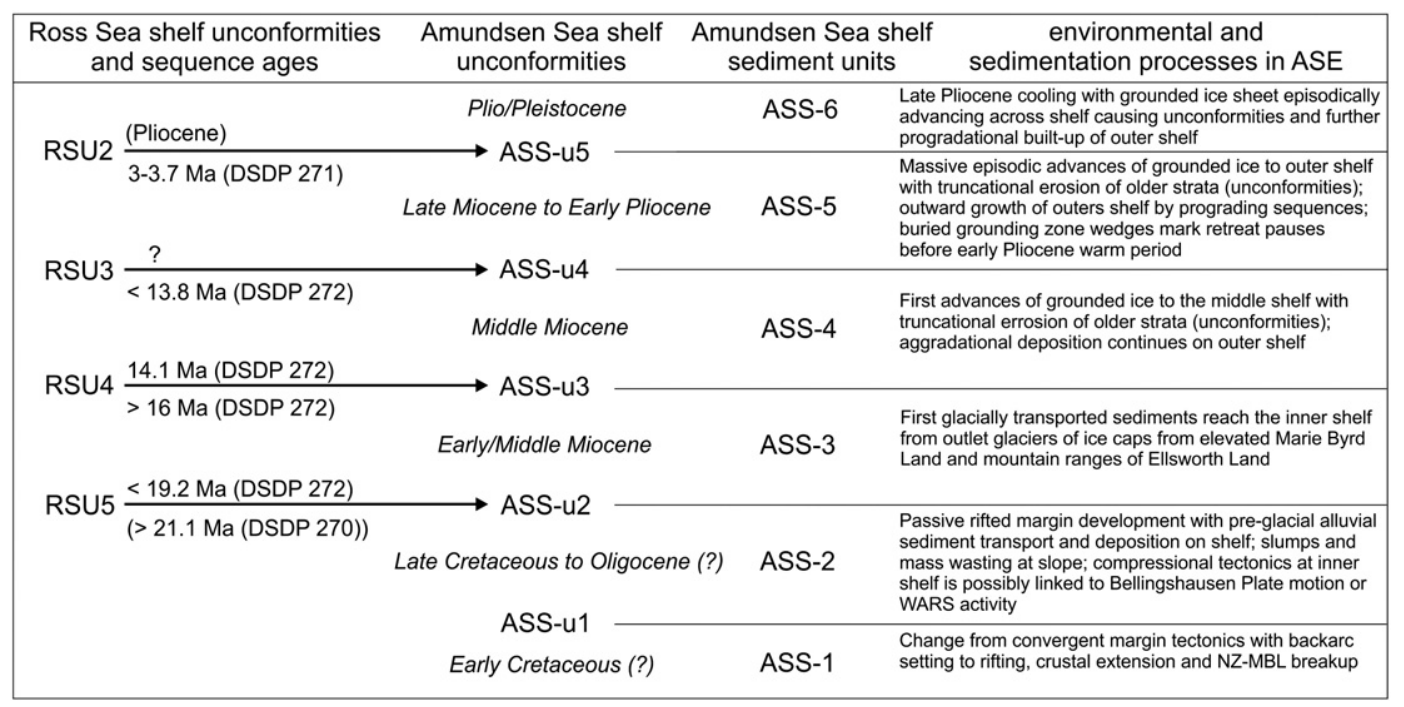

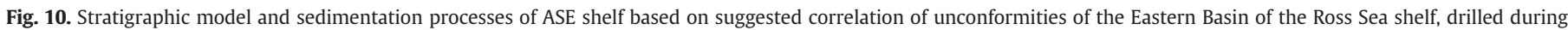

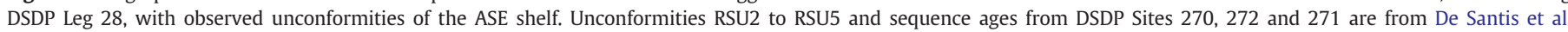
$(1995,1999)$ and Anderson (1999) and references therein. Age epochs suggested for the ASE shelf units are proposed tentatively due to the lack of drill and outcrop records.

al., 2013). We interpret this sub-basin as part of a transtensional or strike-slip/pull-apart West Antarctic Rift System (WARS) branch that accommodated the Byrd Subglacial Basin and Bentley Subglacial Trench of central West Antarctica and extended to the north through the ASE before its rift axis migrated east of the Thurston Island block at about 60 Ma (Müller et al., 2007). Dalziel (2006) postulated the extent of the WARS into the ASE shelf, and our geophysical data confirm the existence of such a basin.

The relatively good coverage of seismic profiles in the eastern ASE allows us to describe the development of the main flow-paths of Pine Island Glacier and Thwaites Glacier across the shelf. We consider the deepest parts of unconformity ASS-u4 in profiles AWI-20100121 (Fig. 7) and AWI-20100133 (Fig. S7) as the base of the initial central Pine Island Trough, which developed when the first grounded ice streams advanced across the middle shelf in the Middle to Late Miocene. Compared to its present bathymetric configuration, the paleo-position of the trough has not changed on the middle shelf segment. Unconformity ASS-u5, marking the onset of enhanced late Pliocene glaciation, also parallels the present seafloor from the middle to outer shelf (Figs. 7, S6, S7). We infer that the central Pine Island Trough, whose location is constrained by the eastern WARS subbasin flank and shallow basement structures along tectonic lineaments (Gohl, 2012; Gohl et al., 2013), remained at the same position on the shelf since early glacial advances. With the growth of the progradational wedge, which moved the shelf break between 25 and $65 \mathrm{~km}$ oceanwards (Fig. 11), the paleo-positions of the PITE and PITW also did not change much on the newly extended outer shelf. A gap in seismic data coverage south of the Eastern Outer Bank (Fig. 1) does not allow us to specify the paleo-position of the glacial trough system between the outer PITW and the central Pine Island Trough. This uncertainty applies also to the western ASE shelf where the seismic data coverage on the outer shelf is relatively sparse. However, our observation of relatively stable paleo-positions of the three branches of Pine Island Trough suggests a glacial history in the ASE that is different from that on the Ross Sea shelf. There, paleo-ice stream troughs shifted more frequently during the early phase of grounded ice-sheet advance, resulting in a greater alongstrike stratigraphic complexity (Alonso et al., 1992; Anderson and Bartek, 1992). The long post-rift, pre-glacial interval in the ASE resulted in a more deeply buried basement before the first ice sheets advanced across the shelf. In contrast, basement control on paleodrainage of ice streams persisted much longer on the Ross Sea and
Antarctic Peninsula shelves (Alonso et al., 1992; Smith and Anderson, 2010; Anderson and Bartek, 1992).

Our seismostratigraphic model of the ASE shelf (Fig. 9) provides the prerequisite for an improved understanding of the West Antarctic paleoenvironment from Cretaceous to Quaternary times and helps to decipher WAIS dynamic history. Unlike the shelves of the Ross Sea and Filchner-Ronne/Weddell Sea embayments, the ASE shelf consists of glacimarine and subglacial sedimentary strata that were entirely supplied from a West Antarctic source and thus from ice drainage basins unaffected by the East Antarctic Ice Sheet. Even for pre-glacial times, the reconstructed Antarctic paleotopography at $34 \mathrm{Ma}$ of Wilson et al. (2012) indicates that an alluvial system draining into the Amundsen Sea had its catchment in the West Antarctic hinterland. Shallow and deep drilling at selected sites on the shelf, slope and rise, identified from the seismic records, would provide records urgently needed for an improved understanding of processes and mechanisms leading to West Antarctic Ice Sheet deglaciation as presently observed in the Amundsen Sea drainage sector.

\section{Conclusions}

This study presents a first seismostratigraphic analysis of the Amundsen Sea Embayment shelf and slope using the extensive seismic profile network acquired in this region during the last decade. The main results are:

- The seismic data outline the geometry of a large pre- and syn-rift basin on the middle shelf between the basement cropping out on the inner shelf and an east-west striking basement ridge and other basement highs on the outer shelf.

- A sub-basin with a NNE-SSW-striking axis underlies the mid-shelf in the eastern ASE. We attribute its formation to transtensional or strike-slip/pull-apart motion along an early WARS branch.

- We identify five major erosional unconformities (from bottom to top: ASS-u1 to ASS-u5) and interpret ASS-u3 as the result of minor erosion caused by early advances of grounded ice onto the middle shelf, and ASS-u4 as the result of major subglacial erosion caused by grounded ice sheet advances onto the middle and outer shelf.

- The reflection characteristics of the seismostratigraphic units identified on the ASE shelf are remarkably similar to those on the Ross Sea shelf for which age models exist from drill records. The unconformities ASS-u2, ASS-u3, ASS-u4 and ASS-u5 correspond, from bottom 


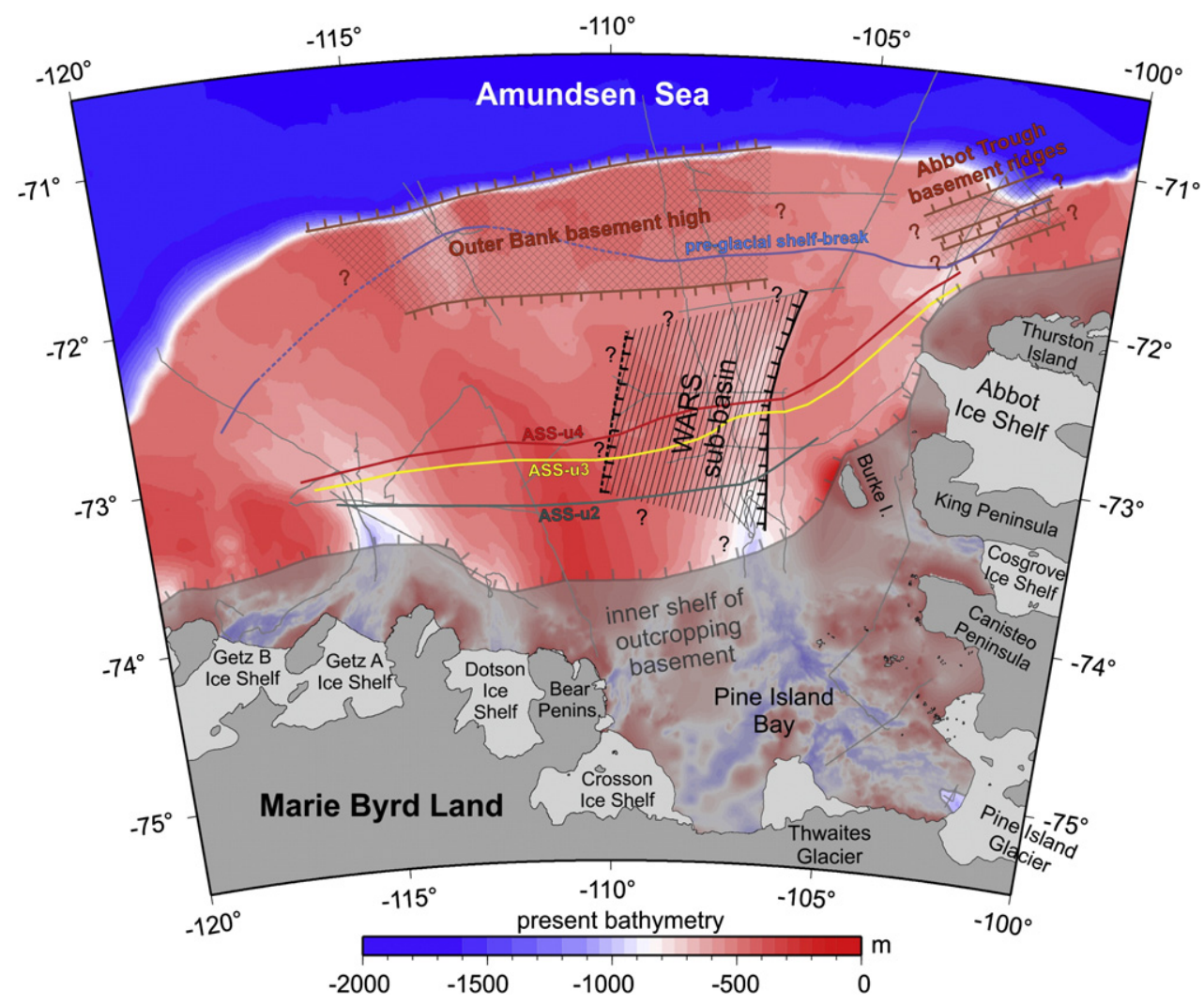

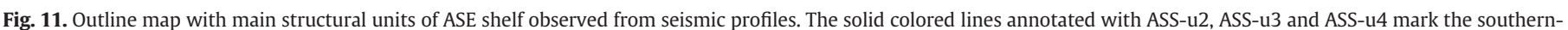

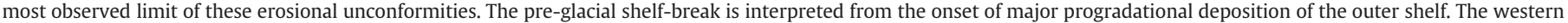

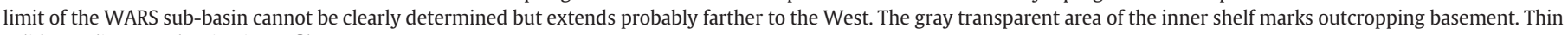
solid gray lines mark seismic profiles.

to top, to the Ross Sea shelf unconformities RSU5, RSU4A (or RSU4), RSU3 and RSU2, respectively. In a chronostratigraphic model for the seismostratigraphic units on the ASE shelf, we assign an Early Cretaceous age to the oldest sedimentary unit ASS-1, a Late Cretaceous to Oligocene age to unit ASS-2, an Early to Mid-Miocene age to unit ASS-3, a Mid-Miocene age to unit ASS-4, a Late Miocene to Early Pliocene age to unit ASS-5, and a Pliocene to Pleistocene age to the top unit ASS-6.

- Numerous minor truncational unconformities within units ASS-u5 and ASS-u6 indicate frequent advance and retreat episodes of grounded ice across the middle and outer shelf in the Late Miocene and Plio/ Pleistocene.

- At least $4 \mathrm{~km}$ of pre-glacial strata were eroded from the present inner shelf and coastal hinterland since the onset of major ice sheet advance across the ASE shelf. Parts of the eroded sediments were deposited as a progradional wedge that extends the outer shelf by 25 to $65 \mathrm{~km}$ oceanward of the pre-glacial shelf break.

- The preservation of buried grounding zone wedges in the upper part of unit ASS-5 on the outer shelf is consistent with prolonged continuous accumulation of (glaci-)marine sediments, probably during a long interglacial period with a significantly reduced WAIS in the early Pliocene as observed on the Ross Sea shelf. A seasonal to permanently open-marine setting, similar as observed for the Ross Sea shelf for the same time, was likely the case.

- The paleo-position of central Pine Island Trough has been constrained by the eastern WARS sub-basin flank and shallow basement structures along tectonic lineaments. Consequently, central Pine Island Trough has remained in the same position on the shelf since early glacial advances. The paleo-positions of the PITE and PITW on the outer shelf also remained unchanged. We explain this difference to the Ross Sea shelf, where paleo-positions of the glacial troughs have shifted more dynamically, by a long post-rift, pre-glacial deposition history and deeper-seated basement on the ASE shelf.
The seismostratigraphic model of the ASE shelf opens the door to an improved understanding of the West Antarctic paleoenvironment from Cretaceous to Quaternary times. Shallow and deep drilling at selected sites on the shelf would provide stratigraphic control, and analyses of paleoclimate proxies on the recovered sediments would help to reconstruct past WAIS dynamics, which would improve the understanding of the processes and mechanisms leading to West Antarctic Ice Sheet deglaciation as presently observed in the Amundsen Sea drainage sector.

Supplementary data to this article can be found online at http:// dx.doi.org/10.1016/j.margeo.2013.06.011.

\section{Acknowledgments}

The authors are grateful for the support of the masters and crews of RV Polarstern during expeditions ANT-XXIII/4 (2006) and ANTXXVI/3 (2010), and of RRS James Clark Ross during expedition JR141 (2006). We extend our gratitude to the seismic teams on board of both vessels, including staff of the British Geological Survey Marine Operations Group on JR141, for successful data acquisition. Geoff Shipton (Triton Imaging) and David Mucciarone (Stanford University) are gratefully acknowledged for their SEG-Y conversion of the native SCS data from the RV Nathaniel B. Palmer cruise NBP9902 (1999). We thank the German Instrument Pool for Amphibian Seismology (DEPAS), hosted by the Alfred Wegener Institute, for providing the ocean-bottom seismometers. We thank John B. Anderson of Rice University for giving permission to use the seismic line NBP9902-11 as well as the seismic image of the PD90-30 line from the Ross Sea shelf for Fig. 4c, and we thank Christopher Sorlien and the ROSSMAP group for providing a section of PD90-30 with interpreted horizons. A large part of this paper was drafted during a research visit of K.G. to GNS Science, New Zealand, funded by the International 
Bureau of the German Federal Ministry of Education and Research (IB-BMBF) through contract no. 01DR12043. The paper improved from the helpful review comments and suggestions by Julia Wellner and John B. Anderson. R.D.L and C.D.H. were supported through the BAS IceSheets Programme which is funded by the UK Natural Environment Research Council. This study has primarily been funded through Work Package 3.2 of the AWI research program PACES.

\section{References}

Alley, R.B., Blankenship, D.D., Rooney, S.T., Bentley, C.R., 1989. Sedimentation beneath ice shelves: the view from ice stream B. Marine Geology 85, 101-120.

Alonso, B., Anderson, J.B., Diaz, J.T., Bartek, L.R., 1992. Pliocene-Pleistocene seismic stratigraphy of the Ross Sea: evidence for multiple ice sheet grounding episodes. In: Elliot, D.H. (Ed.), Contributions to Antarctic Research III. Antarctic Research Series, vol. 57. American Geophysical Union, Washington, D.C, pp. 93-103.

Anderson, J.B., 1999. Antarctic Marine Geology. Cambridge University Press, New York (289 pp.).

Anderson, J.B., Bartek, L.R., 1992. Cenozoic glacial history of the Ross Sea revealed by intermediate resolution seismic reflection data combined with drill site information. In: Kennett, J.P., Warnke, D.A. (Eds.), The Antarctic Paleoenvironment: A Perspective on Global Change, Part One. Antarctic Research Series, vol. 56. American Geophysical Union, Washington, DC, pp. 231-263.

Anderson, J.B., Shipp, S.S., Siringan, F.P., 1992. Preliminary seismic stratigraphy of the northwestern Weddell Sea continental shelf. In: Yoshida, Y., Kaminuma, K. Shiraishi, K. (Eds.), Recent Progress in Antarctic Earth Science. Terra Scientific Publishing, Tokyo, pp. 603-612.

Bamber, J.L., Riva, R.E.M., Vermeersen, B.L.A., LeBrocq, A.M., 2009. Reassessment of the potential sea-level rise from a collapse of the West Antarctic Ice Sheet. Science 324 901-903. http://dx.doi.org/10.1126/science.1169335.

Bart, P.J., 2005. West-directed flow of the West Antarctic Ice Sheet across Eastern Basin, Ross Sea during the Quaternary. Earth and Planetary Science Letters 228, 425-438. http://dx.doi.org/10.1016/j.epsl.2004.10.014.

Brancolini, G., De Santis, L., Lovo, M., Prato, S., 1997. Cenozoic glacial history in the Ross Sea (Antarctica): constraints from seismic reflection data. Terra Antartica 4 (1), 57-60.

Cape Roberts Science Team, 1999. Studies from the Cape Roberts Project, Ross Sea, Antarctica, Initial report on CRP-2/2A. Terra Antartica 6, 1-173.

Cape Roberts Science Team, 2000. Studies from the Cape Roberts Project, Ross Sea, Antarctica, Initial report on CRP-3. Terra Antartica 7, 1-209.

Chow, J.M., Bart, P.J., 2003. West Antarctic Ice Sheet grounding events on the Ross Sea outer continental shelf during the middle Miocene. Palaeogeography, Palaeoclimatology, Palaeoecology 198, 169-186.

Cochrane, G.R., De Santis, L., Cooper, A.K., 1995. Seismic velocity expression of glacial sedimentary rocks beneath the Ross Sea from sonobuoy seismic-refraction data. In: Cooper, A.K., Barker, P.F., Brancolini, G. (Eds.), Geology and Seismic Stratigraphy of the Antarctic Margin. Antarctic Research Series, 68. American Geophysical Union, Washington, DC, pp. 261-270.

Cooper, A.K., Barrett, P.J., Hinz, K., Traube, V., Leitchenkov, G., Stagg, H.M.J., 1991. Cenozoic prograding sequences of the Antarctic continental margins: a record of glacioeustatic and tectonic events. Marine Geology 102, 175-213.

Cooper, A.K., Brancolini, G., Escutia, C., Kristoffersen, Y., Larter, R., Leitchenkov, G., O'Brien, P., Jokat, W., 2008. Cenozoic climate history from seismic-reflection and drilling studies on the Antarctic continental margin. In: Florindo, F., Siegert, M. (Eds.), Antarctic Climate Evolution. Developments in Earth and Environmental Sciences, vol. 8. Elsevier, pp. 115-228.

Dalziel, I.W.D., 2006. On the extent of the active West Antarctic rift system. In: Siddoway, C.S., Ricci, C.A. (Eds.), Proceedings of Workshop on Frontiers and Opportunities in Antarctic Geosciences. Terra Antartica Reports, 12. Terra Antartica Publications, Siena, Italy, pp. 193-202.

Dalziel, I.W.D., Elliot, D.H., 1982. West Antarctica: problem child of Gondwanaland. Tectonics 1, 3-19.

Davy, B., Hoernle, K., Werner, R., 2008. Hikurangi Plateau: crustal structure, rifted formation, and Gondwana subduction history. Geochemistry, Geophysics, Geosystems 9. http://dx.doi.org/10.1029/2007GC001855.

De Santis, L., Anderson, J.B., Brancolini, G., Zayatz, I., 1995. Seismic record of late Oligocene through Miocene glaciation on the Central Eastern continental shelf of Ross Sea. In: Cooper, A.K., Barker, P.F., Brancolini, G. (Eds.), Geology and Seismic Stratigraphy of the Antarctic Margin. Antarctic Research Series, vol. 68. American Geophysical Union, Washington, D.C., pp. 235-260.

De Santis, L., Prato, S., Brancolini, G., Lovo, M., Torelli, L., 1999. The Eastern Ross Sea continental shelf during the Cenozoic: implications for the West Antarctic ice sheet development. Global and Planetary Change 23, 173-196.

Decesari, R.C., Sorlien, C.C., Luyendyk, B.P., Wilson, D.S., Bartek, L., Diebold, J., Hopkins, S.E., 2007. Regional seismic stratigraphic correlations of the Ross Sea: implications for the tectonic history of the West Antarctic Rift System. In: Cooper, A.K., Raymond, C.R. (Eds.), Proceedings of the 10th Int. Symposium of Antarctic Earth Sciences. USGS Open-File Report 2007-1047. http://dx.doi.org/10.3133/of20071047.srp052.

DiVenere, V., Kent, D.V., Dalziel, I.W.D., 1994. Mid-Cretaceous paleomagnetic results from Marie Byrd Land, West Antarctica: A test of post-100 Ma relative motion between East and West Antarctica. Journal of Geophysical Research 99, 15115-15139.
Domack, E., Duran, D., Leventer, A., Ishman, S., Doane, S., McCallum, S., Amblas, D., Ring J., Gilbert, R., Prentice, M., 2005. Stability of the Larsen B ice shelf on the Antarctic Peninsula during the Holocene epoch. Nature 436, 681-685.

Dowdeswell, J.A., Fugelli, E.M.G., 2012. The seismic architecture and geometry of grounding-zone wedges formed at the marine margins of past ice sheets. Geological Society of America Bulletin 124, 1750-1761. http://dx.doi.org/10.1130/B30628.1.

Dowdeswell, J.A., Cofaigh, C.Ó., Anderson, J.B., 2006. Morphology and sedimentary processes on the continental slope off Pine Island Bay, Amundsen Sea, West Antarctica. Geological Society of America Bulletin 118, 606-619.

Drewry, D.J., 1983. Antarctica: Glaciological and Geophysical Folio. Scott Polar Research Institute, Cambridge, UK ( 9 sheets).

Eagles, G., Gohl, K., Larter, R.D., 2004. High-resolution animated tectonic reconstruction of the South Pacific and West Antarctic Margin. Geochemistry, Geophysics, Geosystems 5 (7). http://dx.doi.org/10.1029/2003GC000657.

Ehrmann, W., Hillenbrand, C.-D., Smith, J.A., Graham, A.G.C., Kuhn, G., Larter, R.D., 2011 Provenance changes between recent and glacial-time sediments in the Amundsen Sea embayment, West Antarctica: clay mineral assemblage evidence. Antarctic Science 23, 471-486.

Eittreim, S.L., Cooper, A.K., Wannesson, J., 1995. Seismic stratigraphic evidence of icesheet advances on the Wilkes Land margin of Antarctica. Sedimentary Geology 96, 131-156.

Evans, J., Dowdeswell, J.A., Cofaigh, C.Ó., Benham, T.J., Anderson, J.B., 2006. Extent and dynamics of the West Antarctic Ice Sheet on the outer continental shelf of Pine Island Bay during the last glaciation. Marine Geology 230, 53-70.

Fielding, C.R., Whittaker, J., Henrys, S.A., Wilson, T.J., Naish, T.R., 2008. Seismic facies and stratigraphy of the Cenozoic succession in McMurdo Sound, Antarctica: implications for tectonic, climatic and glacial history. Palaeogeography, Palaeoclimatology, Palaeoecology 260, 8-29. http://dx.doi.org/10.1016/j.palaeo.2007.08.016.

Fretwell, P., et al., 2013. Bedmap2: improved ice bed, surface and thickness datasets for Antarctica. The Cryosphere 7, 375-393. http://dx.doi.org/10.5194/tc-7-375-2013.

Gohl, K., 2007. The Expedition ANTARKTIS-XXIII/4 of the Research Vessel "Polarstern" in 2006. Berichte zur Polar- und Meeresforschung (Reports on Polar and Marine Research) 557 (166 pp., http://epic.awi.de/26756/).

Gohl, K., 2010. The Expedition of the Research Vessel "Polarstern" to the Amundsen Sea, Antarctica, in 2010 (ANT-XXVI/3). Berichte zur Polar- und Meeresforschung (Reports on Polar and Marine Research) 617 (173 pp., http://epic.awi.de/29635/).

Gohl, K., 2012. Basement control on past ice sheet dynamics in the Amundsen Sea Embayment, West Antarctica. Palaeogeography, Palaeoclimatology, Palaeoecology 335-336, 35-41. http://dx.doi.org/10.1016/j.palaeo.2011.02.022.

Gohl, K., Teterin, D., Eagles, G., Netzeband, G., Grobys, J., Parsiegla, N., Schlüter, P. Leinweber, V., Larter, R.D., Uenzelmann-Neben, G., Udintsev, G.B., 2007. Geophysical survey reveals tectonic structures in the Amundsen Sea embayment, Wes Antarctica. In: Cooper, A.K., Raymond, C.R. (Eds.), Proceedings of the 10th Int. Symposium of Antarctic Earth Sciences. USGS Open-File Report 2007-1047. http:// dx.doi.org/10.3133/of2007-1047.srp047.

Gohl, K., Denk, A., Eagles, G., Wobbe, F., 2013. Deciphering tectonic phases of the Amundsen Sea Embayment shelf, West Antarctica, from a magnetic anomaly grid. Tectonophysics 585, 113-123. http://dx.doi.org/10.1016/j.tecto.2012.06.036.

Graham, A.G.C., Larter, R.D., Gohl, K., Hillenbrand, C.-D., Smith, J.A., Kuhn, G., 2009 Bedform signature of a West Antarctic palaeo-ice stream reveals a multitemporal record of flow and substrate control. Quaternary Science Reviews 28, 2774-2793. http://dx.doi.org/10.1016/j.quascirev.2009.07.003.

Graham, A.G.C., Larter, R.D., Gohl, K., Dowdeswell, J.A., Hillenbrand, C.-D., Smith, J.A Evans, J., Kuhn, G., Deen, T.J., 2010. Flow and retreat of the Late Quaternary Pine Island-Thwaites paleo-ice stream, West Antarctica. Journal of Geophysical Research - Earth Surfaces 115. http://dx.doi.org/10.1029/2009JF001482.

Harwood, D., Florindo, F., Talarico, F. Levy, R., Kuhn, G., Naish, T., Niessen, F., Powell, R, Pyne, A., Wilson, G., 2009. Antarctic drilling recovers stratigraphic records from the continental margin. EOS Transactions 90, 90-91.

Hayes, D.E., Frakes, L.A., 1975. General synthesis. Initial Report of the Deep Sea Drilling Project 28. 919-942.

Hemer, M., Post, A.L., O'Brien, P.E., Craven, M., Truswell, E.M., Roberts, D., Harris, P.T. 2007. Sedimentological signatures of the sub-Amery Ice Shelf circulation. Antarctic Science 19, 497-506.

Hillenbrand, C.-D., Smith, J.A., Kuhn, G., Esper, O., Gersonde, R., Larter, R.D., Maher, B. Moreton, S.G., Shimmield, T.M., Korte, M., 2010. Age assignment of a diatomaceous ooze deposited in the western Amundsen Sea Embayment after the Last Glacial Maximum. Journal of Quaternary Science 25, 280-295. http://dx.doi.org/10.1002/jqs.1308.

Hillenbrand, C.-D., Kuhn, G., Smith, J.A., Gohl, K., Graham, A.G.C., Larter, R.D., Klages, J.P., Downey, R., Moreton, S.G., Forwick, M., Vaughan, D.G., 2013. Grounding-line retreat of the West Antarctic Ice Sheet from inner Pine Island Bay. Geology 41, 35-38. http://dx.doi.org/10.1130/G33469.1.

Hochmuth, K., Gohl, K., 2013. Glaciomarine sedimentation dynamics of the Abbot glacial trough of the Amundsen Sea Embayment shelf, West Antarctica. In: Hambrey, M.J., et al. (Ed.), Antarctic Palaeoenvironments and Earth-Surface Processes. Geological Society Special Publications. The Geological Society of London (in press), http://dx.doi.org/10.1144/SP381.21.

Howat, I.M., Domack, E.W., 2003. Reconstructions of western Ross Sea palaeo-ice-stream grounding zones from high-resolution acoustic stratigraphy. Boreas 32, 56-75.

Jakobsson, M., Anderson, J.B., Nitsche, F.O., Dowdeswell, J.A., Gyllencreutz, R., Kirchner N., Mohammad, R., O'Regan, M., Alley, R.B., Anandakrishnan, S., Eriksson, B. Kirshner, A., Fernandez, R., Stolldorf, T., Minzoni, R., Majewski, W., 2011. Geological record of ice shelf break-up and grounding line retreat, Pine Island Bay, West Antarctica. Geology 39, 691-694. http://dx.doi.org/10.1130/G32153.1.

Jakobsson, M., Anderson, J.B., Nitsche, F.O., Gyllencreutz, R., Kirshner, A.E., Kirchner, N O'Regan, M., Mohammad, R., Eriksson, B., 2012. Ice sheet retreat dynamics inferred 
from glacial morphology of the central Pine Island Bay Trough, West Antarctica. Quaternary Science Reviews 38, 1-10. http://dx.doi.org/10.1016/j.quascirev.2011.12.017.

Jordan, T.A., Ferraccioli, F., Vaughan, D.G., Holt, J.W., Corr, H., Blankenship, D.D., Diehl, T.M., 2010. Aerogravity evidence of a major crustal thinning under the Pine Island Glacier region (West Antarctica). Bulletin of the Geological Society of America 122, 714-726. http://dx.doi.org/10.1130/B26417.1.

Kellogg, T.B., Kellogg, D.E., 1987. Late Quaternary deglaciation of the Amundsen Sea: implications for ice sheet modelling. In: Waddington, E.D., Walder, J.S. (Eds.), The Physical Basis of Ice Sheet Modelling, 170. IAHS Publ., pp. 349-357.

Kerr, A., Huybrechts, P., 1999. The response of the East Antarctic ice-sheet to the evolving tectonic configuration of the Transantarctic Mountains. Global and Planetary Change 23, 213-229.

Kipf, A., Mortimer, N., Werner, R., Gohl, K., van den Bogaard, P., Hauff, F., Hoernle, K. 2012. Granitoids and dykes of the Pine Island Bay region, West Antarctica. Antarctic Science 24 (5), 473-484. http://dx.doi.org/10.1017/S0954102012000259.

Kirshner, A.E., Anderson, J.B., Jakobsson, M., O'Regan, M., Majewski, W., Nitsche, F.O., 2012. Post-LGM deglaciation in Pine Island Bay, West Antarctica. Quaternary Science Reviews 38, 11-26. http://dx.doi.org/10.1016/j.quascirev.2012.01.017.

Klages, J.P., Kuhn, G., Hillenbrand, C.-D., Graham, A.G.C., Smith, J.A., Larter, R.D., Gohl, K., 2013. First geomorphological record and glacial history of an inter-ice stream ridge on the West Antarctic continental shelf. Quaternary Science Reviews 61, 47-61. http://dx.doi.org/10.1016/j.quascirev.2012.11.007.

Larter, R.D., Vanneste, L.E., 1995. Relict subglacial deltas on the Antarctic Peninsula outer shelf. Geology 23, 33-36.

Larter, R.D., Rebesco, M., Vanneste, L.E., Gambôa, L.A.P., Barker, P.F., 1997. Cenozoic tectonic, sedimentary and glacial history of the continental shelf west of Graham Land, Antarctic Peninsula. In: Barker, P.F., Cooper, A.K. (Eds.), Geology and Seismic Stratigraphy of the Antarctic Margin 2. Antarctic Research Series, v. 71. American Geophysical Union, pp. 1-27.

Larter, R.D., Cunningham, A.P., Barker, P.F., Gohl, K., Nitsche, F.O., 2002. Tectonic evolution of the Pacific margin of Antarctica - 1. Late Cretaceous tectonic reconstructions. Journal of Geophysical Research 107 (B12), 2345. http://dx.doi.org/ 10.1029/2000JB000052.

Larter, R., Gohl, K., Hillenbrand, C.-D., Kuhn, G., Deen, T.J., Dietrich, R., Eagles, G., Johnson, J.S., Livermore, R.A., Nitsche, F.O., Pudsey, C.J., Schenke, H.-W., Smith, J.A., Udintsev, G. Uenzelmann-Neben, G., 2007. West Antarctic Ice Sheet change since the last glacial period. Eos, Transactions of the American Geophysical Union 88, 189-196.

Larter, R.D., Graham, A.G.C., Gohl, K., Kuhn, G., Hillenbrand, C.-D., Smith, J.A., Deen, T.J. Livermore, R.A., Schenke, H.-W., 2009. Subglacial bedforms reveal complex basal regime in a zone of paleo-ice stream convergence, Amundsen Sea Embayment, West Antarctica. Geology 37 (5), 411-414. http://dx.doi.org/10.1130/G25505A.

LeMasurier, W.E., 2008. Neogene extension and basin deepening in the West Antarctic rift inferred from comparisons with the East African rift and other analogs. Geology 36, 247-250. http://dx.doi.org/10.1130/G24363A.

Levy, R., Cody, R., Crampton, J., Fielding, C., Golledge, N., Harwood, D., Henrys, S. McKay, R., Naish, T., Ohneiser, C., Wilson, G., Wilson, T., Winter, D., 2012. Late Neogene climate and glacial history of the Southern Victoria Land coast from integrated drill core, seismic and outcrop data. Global and Planetary Change 96-97, 157-180. http://dx.doi.org/10.1016/j.gloplacha.2012.02.005.

Lowe, A.L., Anderson, J.B., 2002. Reconstruction of the West Antarctic ice sheet in Pine Island Bay during the Last Glacial Maximum and its subsequent retreat history. Quaternary Science Reviews 21, 1879-1897.

Lowe, A.L., Anderson, J.B., 2003. Evidence for abundant subglacial meltwater beneath the paleo-ice sheet in Pine Island Bay, Antarctica. Journal of Glaciology 46 (164), 125-138.

McKay, R.M., Dunbar, G.B., Naish, T.R., Barrett, P.J., Carter, L., Harper, M., 2008. Retreat history of the Ross Ice Sheet (Shelf) since the Last Glacial Maximum from deepbasin sediment cores around Ross Island. Palaeogeography, Palaeoclimatology, Palaeoecology 260, 245-261. http://dx.doi.org/10.1016/j.palaeo.2007.08.015.

McKay, R., Browne, G., Carter, L., Cowan, E., Dunbar, G., Krissek, L., Naish, T., Powell, R. Reed, J., Talarico, F., Wilch, T., 2009. The stratigraphic signature of the late Cenozoic Antarctic Ice Sheets in the Ross Embayment. Geological Society of America Bulletin 121, 1537-1561. http://dx.doi.org/10.1130/B26540.1.

McKay, R., Naish, T., Carter, L., Riesselman, C., Dunbar, R., Sjunneskog, C., Winter, D., Sangiorgi, F., Warren, C., Pagani, M., Schouten, S., Willmott, V., Levy, R., DeConto, R. Powell, R.D., 2012. Antarctic and Southern Ocean influences on Late Pliocene global cooling. Proceedings of the National Academy of Sciences of the United States of America (PNAS) 109, 6423-6428. http://dx.doi.org/10.1073/pnas.1112248109.

Mukasa, S.B., Dalziel, I.W.D., 2000. Marie Byrd Land, West Antarctica: evolution of the Gondwana's Pacific margin constrained by zircon U-Pb geochronology and feldspar common- $\mathrm{Pb}$ isotopic compositions. Geological Society of America Bulletin $112,611-627$.

Müller, R.D., Gohl, K., Cande, S.C., Goncharov, A., Golynsky, A.V., 2007. Eocene to Miocene geometry of the West Antarctic rift system. Australian Journal of Earth Sciences 54, 1033-1045. http://dx.doi.org/10.1080/08120090701615691.

Naish, T., Powell, R., Levy, R., Wilson, G., Scherer, R., Talarico, F., Krissek, L., Niessen, F., Pompilio, M., Wilson, T., Carter, L., DeConto, R., Huybers, P., McKay, R., Pollard, D., Ross, J., Winter, D., Barrett, P., Browne, G., Cody, R., Cowan, E., Crampton, J., Dunbar, G., Dunbar, N., Florindo, F., Gebhardt, C., Graham, I., Hannah, M., Hansaraj, D. Harwood, D., Helling, D., Henrys, S., Hinnov, L., Kuhn, G., Kyle, P., Läufer, A., Maff oli, P., Magens, D., Mandernack, K., McIntosh, W., Millan, C., Morin, R., Ohneiser, C., Paulsen, T., Persico, D., Raine, I., Reed, J., Riesselman, C., Sagnotti, L., Schmitt, D. Sjunneskog, C. Strong P. Taviani, M., Vogel, S., Wilch, T., Williams, T, 2009. Obliquity-paced Pliocene West Antarctic ice sheet oscillations. Nature 458, 322-328. http:// dx.doi.org/10.1038/nature07867.
Nitsche, F.O., Gohl, K., Vanneste, K., Miller, H., 1997. Seismic expression of glacially deposited sequences in the Bellingshausen and Amundsen Seas, West Antarctica. In: Barker, P.F., Cooper, A.K. (Eds.), Geology and Seismic Stratigraphy of the Antarctic Margin 2. Antarctic Research Series, Vol. 71. American Geophysical Union, Washington, D.C., pp. 95-108.

Nitsche, F.O., Cunningham, A.P., Larter, R.D., Gohl, K., 2000. Geometry and development of glacial continental margin depositional systems in the Bellingshausen Sea. Marine Geology 162, 277-302.

Nitsche, F.O., Jacobs, S.S., Larter, R.D., Gohl, K., 2007. Bathymetry of the Amundsen Sea continental shelf: implications for geology, oceanography, and glaciology. Geochemistry, Geophysics, Geosystems 8 (10). http://dx.doi.org/10.1029/2007GC001694.

Nitsche, F.O., Gohl, K., Larter, R., Hillenbrand, C.-D., Kuhn, G., Smith, J., Jacobs, S., Anderson, J., Jakobsson, M., 2013. Paleo ice flow and subglacial meltwater dynamics in Pine Island Bay, West Antarctica. The Cryosphere 7, 249-262. http://dx.doi.org/10.5194/ tc-7-249-2013.

Pankhurst, R.J., Millar, I.L., Grunow, A.M., Storey, B.C., 1993. The pre-Cenozoic magmatic history of the Thurston Island crustal block, West Antarctica. Journal of Geophysical Research 98, 11835-11849.

Pankhurst, R.J., Weaver, S.D., Bradshaw, J.D., Storey, B.C., Ireland, T.R., 1998. Geochronology and geochemistry of pre-Jurassic superterranes in Marie Byrd Land, Antarctica. Journal of Geophysical Research 103, 2529-2547.

Pollard, D., DeConto, R.M., 2009. Modelling West Antarctic ice sheet growth and collapse through the past five million years. Nature 458. http://dx.doi.org/10.1038/ nature 07809 .

Pritchard, H.D., Ligtenberg, S.R.M., Fricker, H.A., Vaughan, D.G., van den Broeke, M.R., Padman, L., 2012. Antarctic ice-sheet loss driven by basal melting of ice shelves. Nature 484, 502-505. http://dx.doi.org/10.1038/nature10968.

Pudsey, C.J., Evans, J., 2001. First survey of Antarctic sub-ice shelf sediments reveals mid-Holocene ice shelf retreat. Geology 29, 787-790.

Rignot, E., 2008. Changes in West Antarctic ice stream dynamics observed with ALOS PALSAR data. Geophysical Research Letters 35. http://dx.doi.org/10.1029/ 2008 GL033365.

Rignot, E., Mouginot, J., Scheuchl, B., 2011. Ice flow of the Antarctic ice sheet. Science 333. http://dx.doi.org/10.1126/science.1208336.

Rocchi, S., LeMasurier, W.E., Di Vincenzo, G., 2006. Oligocene to Holocene erosion and glacial history in Marie Byrd Land, West Antarctica, inferred from exhumation of the Dorrel rock intrusive complex and from volcano morphologies. Geological Society of America Bulletin 118, 991-1005. http://dx.doi.org/10.1130/ B25675.1.

Smith, R.T., Anderson, J.B., 2010. Ice-sheet evolution in James Ross Basin, Weddell Sea margin of the Antarctic Peninsula: The seismic stratigraphic record. Geological Society of America Bulletin 122, 830-842. http://dx.doi.org/10.1130/B26486.1.

Smith, J.A. Hillenbrand, C.-D., Larter, R.D., Graham, A.G.C. Kuhn, G., 2009. The sediment infill of subglacial meltwater channels on the West Antarctic continental shelf. Quaternary Research 71, 190-200.

Smith, J.A., Hillenbrand, C.-D., Kuhn, G., Larter, R.D., Graham, A.G.C., Ehrmann, W., Moreton, S.G., Forwick, M. 2011. Deglacial history of the West Antarctic Ice Sheet in the western Amundsen Sea Embayment. Quaternary Science Reviews 30, 488-505.

Sorlien, C.C., Luyendyk, B.P., Wilson, D.S., Decesari, R.C., Bartek, L., Diebold, J.B., 2007. Oligocene development of the West Antarctic Ice Sheet recorded in eastern Ross Sea strata. Geology 35, 467-470. http://dx.doi.org/10.1130/G23387A.

Storey, B.C., 1991. The crustal blocks of West Antarctica within Gondwana: reconstruction and break-up model. In: Thomson, M.R.A., Crane, J.A., Thomson, J.W. (Eds.), Geological Evolution of Antarctica. Cambridge University Press, Cambridge.

Tucholke, B.E., Edgar, N.T., Boyce, R.E., 1976. Physical properties of sediments and correlations with acoustic stratigraphy: Leg 35, deep sea drilling project. In: Hollister, C.D., Craddock, C. (Eds.), Initial Reports. Deep Sea Drilling Project, Washington, D.C., pp. 229-249.

Uenzelmann-Neben, G., Gohl, K., 2012. Amundsen Sea sediment drifts: archives of modifications in oceanographic and climatic conditions. Marine Geology 299-302, 51-62. http://dx.doi.org/10.1016/j.margeo.2011.12.007.

Uenzelmann-Neben, G., Gohl, K., Larter, R.D., Schlüter, P., 2007. Differences in ice retreat across Pine Island Bay, West Antarctica, since the Last Glacial Maximum: indications from multichannel seismic reflection data. In: Cooper, A.K. Raymond, C.R. (Eds.). Proceedings of the 10th Int. Symposium of Antarctic Earth Sciences. USGS Open-File Report 2007-1047. http://dx.doi.org/10.3133/of2007-1047.srp084.

Weigelt, E., Gohl, K., Uenzelmann-Neben, G., Larter, R.D., 2009. Late Cenozoic ice sheet cyclicity in the western Amundsen Sea Embayment-evidence from seismic records. Global and Planetary Change 69, 162-169.

Weigelt, E., Uenzelmann-Neben, G., Gohl, K., Larter, R.D., 2012. Did massive glacial dewatering modify the sedimentary structures of the Amundsen Sea Embayment shelf, West Antarctica? Global and Planetary Change 92-93, 8-16. http:// dx.doi.org/10.1016/j.gloplacha.2012.04.006.

Wellner, J.S., Lowe, A.L., Shipp, S.S., Anderson, J.B., 2001. Distribution of glacial geomorphic features on the Antarctic continental shelf and correlation with substrate: implications for ice behavior. Journal of Glaciology 48, 397-411.

Wilson, D.S., Jamieson, S.S., Barrett, P.J., Leitchenkov, G., Gohl, K., Larter, R.D., 2012. Antarctic topography at the Eocene-Oligocene boundary. Palaeogeography, Palaeoclimatology, Palaeoecology 335-336, 24-34. http://dx.doi.org/10.1016/ j.palaeo.2011.05.028

Wobbe, F., Gohl, K., Chambord, A., Sutherland, R., 2012. Structure and breakup history of the rifted margin of West Antarctica in relation to Cretaceous separation from Zealandia and Bellingshausen plate motion. Geochemistry, Geophysics, Geosystems 13, Q04W12. http://dx.doi.org/10.1029/2011GC003742. 